\title{
Brain-Derived Neurotrophic Factor Signaling Does Not Stimulate Subventricular Zone Neurogenesis in Adult Mice and Rats
}

\author{
Rui P. Galvão, ${ }^{1,2}$ José Manuel Garcia-Verdugo, ${ }^{3}$ and Arturo Alvarez-Buylla ${ }^{1}$ \\ ${ }^{1}$ Department of Neurological Surgery and Institute for Regeneration Medicine, University of California at San Francisco, San Francisco, California 94143 , \\ ${ }^{2}$ Instituto Gulbenkian de Ciência, 2780 Oeiras, Portugal, and ${ }^{3}$ Laboratorio de Morfologia Celular, Unidad Mixta Centro de Investigación Príncipe Felipe, \\ University of Valencia, El Centro de Investigación Biomédica en Red sobre Enfermedades Neurodegenerativas, Valencia 46012, Spain
}

\begin{abstract}
In rodents, the adult subventricular zone (SVZ) generates neuroblasts which migrate to the olfactory bulb (OB) and differentiate into interneurons. Recent work suggests that the neurotrophin Brain-Derived Neurotrophic Factor (BDNF) can enhance adult SVZ neurogenesis, but the mechanism by which it acts is unknown. Here, we analyzed the role of BDNF and its receptor TrkB in adult SVZ neurogenesis. We found that TrkB is the most prominent neurotrophin receptor in the mouse SVZ, but only the truncated, kinasenegative isoform (TrkB-TR) was detected. TrkB-TR is expressed in SVZ astrocytes and ependymal cells, but not in neuroblasts. TrkB mutants have reduced SVZ proliferation and survival and fewer new OB neurons. To test whether this effect is cell-autonomous, we grafted SVZ cells from TrkB knock-out mice (TrkB-KO) into the SVZ of wild-type mice (WT). Grafted progenitors generated neuroblasts that migrated to the $\mathrm{OB}$ in the absence of TrkB. The survival and differentiation of granular interneurons and Calbindin ${ }^{+}$periglomerular interneurons seemed unaffected by the loss of TrkB, whereas dopaminergic periglomerular neurons were reduced. Intra-ventricular infusion of BDNF yielded different results depending on the animal species, having no effect on neuron production from mouse SVZ, while decreasing it in rats. Interestingly, mice and rats also differ in their expression of the neurotrophin receptor p75. Our results indicate that TrkB is not essential for adult SVZ neurogenesis and do not support the current view that delivering BDNF to the SVZ can enhance adult neurogenesis.
\end{abstract}

Key words: neurotrophin; BDNF; TrkB; subventricular zone; neurogenesis; olfactory bulb; p75

\section{Introduction}

Neurogenesis continues throughout adulthood in vertebrates, because of endogenous progenitor cells which could be useful for brain repair (Lie et al., 2004). In rodents, there are two known adult neurogenic regions: the subventricular zone (SVZ) and the hippocampal dentate gyrus. The SVZ contains $\mathrm{GFAP}^{+}$, astrocytic stem cells (type B cells), which generate highly proliferative transient amplifying cells (type $\mathrm{C}$ cells) that differentiate into neuroblasts (type A cells) (Alvarez-Buylla and Garcia-Verdugo, 2002). These neuroblasts migrate in chains through the SVZ (Doetsch and Alvarez-Buylla, 1996) and rostral migratory stream (RMS) to the olfactory bulb (OB) (Luskin, 1993; Lois and Alvarez-Buylla, 1994), where cells migrate radially into the gran-

\footnotetext{
Received June 23, 2008; revised Sept. 20, 2008; accepted 0ct. 11, 2008.

This work was supported by the National Institutes of Health Grant HD 32116 and the John G. Bowes Research Fund. R.P.G. was also supported by the Fundação para a Ciência e Tecnologia. A.A.B. holds the Heather and Melanie Muss Endowed Chair. We thank Dr. Louis Reichardt and Dr. Moses Chao for helpful discussions and for providing various reagents to this project, including the conditional TrkB ${ }^{\text {lox/lox }}$ mice (Louis Reichardt) and antibodies against p75 receptor (Louis Reichardt and Moses Chao) and pTrkB (Moses Chao). We also thank Dr. Domingos Henrique and Dr. Steven Goldman for their insight on this work. We are grateful to Dr. Minoree Kohwi for her advice on all aspects of this study and to Lily Edmondson for technical assistance with quantitative RT-PCR experiments.

Correspondence should be addressed to Arturo Alvarez-Buylla, University of California at San Francisco, Box 0525, San Francisco, CA 94143. E-mail: abuylla@stemcell.ucsf.edu.

DOI:10.1523/JNEUROSCI.2918-08.2008

Copyright $\odot 2008$ Society for Neuroscience $\quad$ 0270-6474/08/2813368-16\$15.00/0
}

ular (GCL) and glomerular (GL) layers and differentiate into inhibitory interneurons (Carleton et al., 2003). We still know very little about the molecules that regulate the generation of thousands of neuroblasts daily from the SVZ.

Growth factors are important components of stem cell niches (Horner and Palmer, 2003). Cells in the SVZ respond to multiple extracellular factors, including EGF, FGF2, PDGF, BMPs, noggin, prolactin and erythropoietin, which influence SVZ proliferation and neurogenesis (Craig et al., 1996; Kuhn et al., 1997; Lim et al., 2000; Shingo et al., 2001, 2003; Zheng et al., 2004; Jackson et al., 2006). Recent findings indicate that neurotrophins may also play a fundamental role in adult neurogenesis. Neurotrophins are well known for promoting neuronal survival and for modulating synaptic plasticity (Schinder and Poo, 2000; Huang and Reichardt, 2001; Chao, 2003). Two laboratories have now reported that exposing the SVZ to the neurotrophin brain-derived neurotrophic factor (BDNF) increases production of OB interneurons and, unexpectedly, of striatal neurons normally not generated in adult brains (Zigova et al., 1998; Benraiss et al., 2001; Pencea et al., 2001; Chmielnicki et al., 2004). Another neurotrophin, CNTF, has been suggested to stimulate adult neurogenesis in the hypothalamus (Kokoeva et al., 2005). Although these findings are of significant interest for regenerative therapies, we still do not understand the biological mechanisms underlying these 
neurotrophins' effects on adult stem cell niches. Most importantly, we do not know which cells directly respond to these neurotrophins nor the nature of their response.

We addressed these questions in the SVZ, focusing on the postulated neurogenic effects of BDNF and its receptors TrkB and $\mathrm{p} 75$. TrkB exists in two isoforms: a full-length receptor, activated by intracellular domain cross-phosphorylation, and a truncated receptor, lacking most of the intracellular region (Klein et al., 1989, 1990; Middlemas et al., 1991). p75 binds several neurotrophins and its activation can affect cell survival, proliferation, migration, axonal elongation and synaptic plasticity (Dechant and Barde, 2002; Barker, 2004). p75 seems to affect neurogenesis from SVZ progenitors (Young et al., 2007). We found that truncated TrkB is expressed in type B and ependymal cells, but not in neuroblasts, whereas p75 is expressed in type C cells and neuroblasts. Our data show that SVZ neurogenesis can continue in the absence of TrkB and that most TrkB-KO and WT OB interneurons display similar survival and differentiation. Importantly, BDNF did not increase SVZ neurogenesis in mice and even decreased neurogenesis in rats.

\section{Materials and Methods}

Animals. Mice and rats were maintained in standard conditions with food and water ad libitum. All experimental procedures were approved by the UCSF Committee on Animal Health and Care. All rat experiments were performed on adult male Sprague Dawley rats $(\sim 250 \mathrm{~g})$ purchased from Charles River Laboratories. For gene expression analysis and graft recipients, adult CD-1 mice were purchased from Charles River Laboratories. Conditional TrkB ${ }^{\text {lox/lox }}$ mutant mice, a kind gift from Louis Reichardt (Xu et al., 2000a) were crossed to $\beta$-actin:cre mice (Lewandoski et al., 1997) to generate a constitutive TrkB reporter line (TrkB: Tau-LacZ), in which cDNA encoding the fusion protein Tau-LacZ is under the control of the endogenous TrkB gene promoter. These mice were used to study the expression of TrkB gene in the SVZ and RMS. TrkB:Tau-LacZ mice were also used as a constitutive TrkB mutant line. For grafting experiments, we crossed TrkB:Tau-LacZ mice to $\beta$-actin: GFP mice (Hadjantonakis et al., 1998), thus generating TrkB constitutive mutant mice whose cells can be traced by GFP expression. Genotyping for GFP transgene was performed by fluorescence in mouse tail samples. Genotyping for all other genes was performed by PCR, using the following primer sequences: N2 (ATGTCGCCCTGGCTGAAGTG) and C8 (ACTGACATCCGTAAGCCAGT) for wild-type TrkB allele, N2 and C7 (GATGATTTCTAGCCTTTTCTGG) for floxed TrkB allele, Tau1 (CAGGCTCTGAAACCTCTGATGC) and Tau2 (GTCATCGGGTCCAGTCCCATC) for deleted TrkB allele.

Histology. For cryostat sectioning, animals were deeply anesthetized with Avertin (Tribromoethanol, mice) or Ketamine/Xylazine (rats) and transcardially perfused with a $0.9 \%$ saline solution. Brains were then removed and immediately frozen in methyl butane at $-40^{\circ} \mathrm{C}$ and 10 $\mu \mathrm{m}$-thick sections (12 $\mu \mathrm{m}$ for rat brains) were cut on a cryostat. Cryosectioning of early postnatal animals was performed on brains embedded in O.C.T. (Sakura): brains were dissected out of the skull and immersed in O.C.T. for $30 \mathrm{~min}$ at $4^{\circ} \mathrm{C}$ and subsequently transferred to a plastic mold filled with O.C.T. and frozen in dry ice-chilled ethanol. Before use, all cryostat sections were thawed/dried at room temperature for $10 \mathrm{~min}$, then fixed $10 \mathrm{~min}$ in $4 \%$ paraformaldehyde (PFA). For vibratome sectioning, animals were deeply anesthetized with Avertin (mice) or Ketamine/Xylazine (rats) and transcardially perfused with $0.9 \%$ saline followed by $4 \%$ PFA in $0.1 \mathrm{M}$ phosphate buffer. Brains were then removed and postfixed overnight at $4^{\circ} \mathrm{C}$ in $4 \%$ PFA. After washing off the PFA with PBS, $50-\mu \mathrm{m}$-thick sections were cut on a vibratome.

Electron microscopy. Adult TrkB:Tau-LacZ reporter mice were transcardially perfused with $2.5 \%$ glutaraldehyde and $2 \%$ paraformaldehyde (PFA). The brains were postfixed overnight in $2.5 \%$ glutaraldehyde at $4^{\circ} \mathrm{C}$, then cut on a vibratome ( $100 \mu \mathrm{m}$ sections). Sections were stained for $\beta$-Gal enzymatic activity for $24 \mathrm{~h}$ at $37^{\circ} \mathrm{C}$. Sections were then incubated $1.5 \mathrm{~h}$ in $\mathrm{OsO}_{4}$, then $3.5 \mathrm{~h}$ in uranyl acetate. After being dehydrated in ethanol, sections were embedded in Araldite. Further processing and imaging was performed as previously described (Doetsch et al., 1997).

Semiquantitative RT-PCR. Total RNA was isolated from freshly dissected mouse tissue using Trizol reagent and protocol (Invitrogen, Cat. \#15596-026), then DNAase-digested to eliminate genomic DNA contaminants. cDNA was generated using random decamers and the Cellsto-Signal kit (Ambion, Cat. \#AM1723). PCR primers were designed using Primer Express software (Applied Biosystems). To prevent nonspecific amplifications, we designed primers to span at least 1 exon/ intron boundary (except BDNF, NT4, TrkB-TR) and selected primer sequences with no significant homology to undesired sequences (as determined by BLAST software). Primer efficiency was further tested by serial dilution of control cDNA samples and melting curve analysis. PCRs were performed on Applied Biosystems 7900HT light cycler, using AmpliTaq Gold DNA polymerase (Applied Biosystems, Cat. \#4311806) and SYBR Green dye (Molecular Probes), which fluoresces when bound to double-stranded DNA and excited by a light source.

Bromodeoxyuridine administration. For label retention and grafting experiments, the DNA synthesis marker bromodeoxyuridine (BrdU) was administered to mice in drinking water $(1 \mathrm{mg} / \mathrm{ml})$ for 1 week or $3 \mathrm{~d}$, respectively. For quantification of neurogenesis in TrkB heterozygous and WT mice, BrdU was injected once intraperitoneally at $50 \mathrm{mg} / \mathrm{kg}$ at postnatal day 21 (P21) and mice were killed and analyzed $15 \mathrm{~d}$ later. For BDNF infusion experiment in mice and rats, BrdU was injected intraperitoneally (IP) at $50 \mathrm{mg} / \mathrm{kg}$ every $4 \mathrm{~d}$ after surgery. In a second BDNF infusion experiment performed in rats, BrdU was injected IP at 120 $\mathrm{mg} / \mathrm{kg}$ every $2 \mathrm{~h}$ for a total of 5 injections $4 \mathrm{~d}$ after surgery, as previously described (Zigova et al., 1998).

In situ hybridization. In situ hybridization was performed as described previously (Fior and Henrique, 2005), with modifications. Briefly, cryostat sections were fixed $10 \mathrm{~min}$ in $4 \%$ PFA, acetylated and incubated overnight in highly stringent conditions $(50 \%$ formamide, $3 \times$ SSC, $60^{\circ} \mathrm{C}$ ) with DIG-labeled RNA probes. Unbound probes were removed with $50 \%$ formamide $/ 1 \times$ SSC and MABT washes. Tissue was blocked in $2 \%$ blocking reagent (Roche, \#1096176) and 20\% goat serum, then incubated overnight at $4^{\circ} \mathrm{C}$ with anti-DIG/AP antibody (1:2000, Roche, $\# 11093274910)$. Sections were then washed with MABT and incubated in AP staining buffer (100 mm NaCl, $50 \mathrm{~mm}$ Tris $\mathrm{pH} 9.5,100 \mathrm{~mm} \mathrm{MgCl}_{2}$, $0.1 \%$ Tween 20 ) with NBT/BCIP substrate. Staining was performed at $37^{\circ} \mathrm{C}$ for $2-5 \mathrm{~h}$. A probe specific for the full-length isoform of TrkB (TrkB-FL) was generated as follows: a 1000 base pair sequence unique to TrkB-FL was amplified by PCR from total mouse brain cDNA using the primers TTGGCATCACCAACAGTCAGC and GTCAGCGGCAGTCAAGAGGTT (see sequence \#NM_001025074 for TrkB-FL). This fragment was then purified and cloned using a T/A cloning kit (Invitrogen). The cloned fragment was sequenced to confirm that the correct DNA sequence had been cloned.

Western blot. SVZ, striatum or whole brain were dissected and triturated in RIPA buffer (1\% Triton X100, 0.1\% SDS, 5 mм EDTA, 1\% deoxycholic acid in PBS, protease inhibitors added before use) with a 27 -gauge needle. Protein amounts were quantified by Bradford method and run on a denaturing gel loading 10-20 $\mu \mathrm{g}$ of protein/well. Protein was electrotransferred to a PVDF membrane, which was then blocked $1 \mathrm{~h}$ at room temperature ( $5 \%$ skimmed milk; blocking for Upstate anti-TrkB antibody was done overnight at $4^{\circ} \mathrm{C}$ ). Primary antibodies against TrkB (Upstate, Santa Cruz Biotechnology, Chemicon), pTrkB (1:1000, or 0.18 $\mu \mathrm{g} / \mathrm{ml}$, a kind gift from Moses Chao, Department of Cell Biology, Skirball Institute, New York, NY) and $\beta$-actin (AbCam) (see Table 2 for details) were incubated overnight at $4^{\circ} \mathrm{C}$. Secondary antibody was incubated in blocking solution $1 \mathrm{~h}$ at room temperature: goat anti-rabbit-HRP (1: 5000, AbCam, \#ab6721). Membrane was developed using ECL Plus reagent (GE Healthcare, \#RPN2132).

TUNEL. TUNEL was performed on cryostat sections, using the Cell Death Detection kit (Roche, Cat. \#12156792910). Tissue sections were dried at room temperature for $10 \mathrm{~min}$, then fixed in 4\% PFA for $20 \mathrm{~min}$. Tissue was then washed in PBS and pretreated by microwaving $1 \mathrm{~min}$ (High setting) in Citrate buffer, after which we followed the manufacturer's instructions for staining.

Immunohistochemistry. Immunostaining and Western blot for TrkB 
were done with a rabbit anti-TrkB from Upstate (see Fig. $2 D-G$ ) as well as 3 other anti-TrkB antibodies from different sources (supplemental Fig. 2, available at www.jneurosci.org as supplemental material) (see Table 2 for details). Immunostaining for p75 (see Fig. 7) was done using the anti-p75 antibody offered by Louis Reichardt (Department of Physiology and Biochemistry/Biophysics, University of California, San Francisco, San Francisco, CA). Additional anti-p75 antibodies from Promega (used on mouse and rat tissue), Chemicon and kind gifts from Moses Chao (used on rat tissue) were used to confirm p75 expression pattern (data not shown) (see Table 2). The following Alexa-conjugated secondary antibodies (Molecular Probes) were used for fluorescence detection: donkey anti-rabbit 488, donkey anti-rabbit 594, donkey anti-mouse 488, donkey anti-mouse 594, goat anti-chicken 488 , goat anti-mouse IgG1 594, goat anti-mouse IgM 594 (all diluted 1:500). $\beta$-Galactosidase and BrdU stainings were amplified using a biotinylated goat anti-mouse $\operatorname{IgG} 2 \mathrm{a}$ (1:500, Southern Biotech) or a biotinylated donkey anti-rat (1:500, Jackson Immunoresearch) secondary antibody, respectively, followed by $1 \mathrm{~h}$ incubation with Streptavidin-Cy2 (1:500, Jackson Immunoresearch) or Streptavidin-488 (1:500, Molecular Probes), respectively. For BrdU detection, $10 \mu \mathrm{m}$ cryostat sections were pretreated with $2 \mathrm{~N} \mathrm{HCl} 30 \mathrm{~min}$ at $37^{\circ} \mathrm{C}$, then washed with Boric acid buffer $(0.1 \mathrm{M}$ boric acid, $0.02 \mathrm{M}$ sodium tetraborate (Borax), pH 8.4) and PBS. Whenever BrdU and another antigen were detected in the same sample, staining was done sequentially, first for the other antigen and postfixing $10 \mathrm{~min}$ with $4 \% \mathrm{PFA}$ before performing the $\mathrm{HCl}$ treatment. All samples were blocked $1 \mathrm{~h}$ at room temperature with $3 \%$ bovine serum albumin (BSA), 10\% serum and $0.1 \%$ Triton X-100. All primary antibodies (except anti-BDNF antibody; see below for details) were incubated overnight at $4^{\circ} \mathrm{C}$ and secondary antibodies $1 \mathrm{~h}$ at room temperature. For the direct detection of TrkB protein on SVZ cells, SVZ was dissected and triturated in PBS. A 3:1 ratio of cells:Matrigel was then applied to a glass coverslip, allowed to solidify $1 \mathrm{~h}$ in a humidified incubator, then fixed 10 min with 4\% PFA. The cell sample was then used for immunocytochemical detection as described above.

BDNF immunohistochemistry. Adult mice were perfused with AcetateBuffered Saline (ABS; $5 \%$ acetic acid in $0.9 \%$ saline, pH 3.0) (Zhou et al., 1994). This perfusion method is not compatible with BrdU labeling. Thus, BDNF and BrdU immunostainings on pump-infused animals were performed on different mice. Brains were then removed and immediately frozen in methyl butane at $-40^{\circ} \mathrm{C}$ and $10-\mu \mathrm{m}$-thick sections were cut on a cryostat. Before use, sections were thawed/dried at room temperature for $10 \mathrm{~min}$ and fixed $10 \mathrm{~min}$ in $100 \%$ methanol prechilled at $-20^{\circ} \mathrm{C}$. Sections were then incubated with $3 \% \mathrm{H}_{2} \mathrm{O}_{2}$ (diluted in PBS) 30 $\mathrm{min}$ at room temperature to inactivate endogenous peroxidase activity. Tissue was blocked $1 \mathrm{~h}$ at room temperature with $3 \%$ bovine serum albumin (BSA) and 10\% serum, and then incubated for 4 overnights at $4^{\circ} \mathrm{C}$ with a rabbit anti-BDNF antibody (see Table 2). We then used a biotinylated donkey anti-rabbit secondary antibody (Jackson Immunoresearch; $1 \mathrm{~h}$ at room temperature) and Vector Laboratories ABC kit and $\mathrm{DAB}$ substrate to stain the tissue.

pTrkB immunohistochemistry. The antibody against phosphorylated TrkB receptor was a kind gift from Moses Chao (see Table 2). Vibratome sections were blocked $1 \mathrm{~h}$ at room temperature with $8 \%$ normal goat serum and $0.1 \%$ Triton X100 in TBS, then washed once with TBS and incubated with $\mathrm{p}$ TrkB antibody overnight at room temperature, then $48 \mathrm{~h}$ at $4^{\circ} \mathrm{C}(1: 200$, or $0.9 \mu \mathrm{g} / \mathrm{ml}$, diluted in $2 \%$ normal goat serum and $0.01 \%$ Triton X100 in TBS).

Cell culture. To test the specificity of the pTrkB antibody, we cultured E18 Sprague Dawley rat hippocampal neurons as described by Bath et al. (2008). Dissected tissue was triturated by repeated pipetting through a 1 $\mathrm{ml}$ Rainin pipette tip, resuspended in Neurobasal medium supplemented with B27, L-glutamine $(0.5 \mathrm{~mm})$ and antibiotics/antimicotics, and plated at $5 \times 10^{6}$ cells/well in a 6 -well plate coated overnight with poly-D-lysine $(0.01 \mathrm{mg} / \mathrm{ml})$. After $3 \mathrm{~d}$ in culture, the cells were exposed to $50 \mathrm{ng} / \mathrm{ml}$ BDNF for $10 \mathrm{~min}$. We then collected the cultured cells in RIPA buffer and processed for Western blot analysis (supplemental Fig. $4 \mathrm{~N}$, available at www.jneurosci.org as supplemental material).

All other cultures were performed with tissue obtained from 1- to 3-d-old mice, except SVZ astrocyte cultures (supplemental Fig.
$11 A, D, G$, available at www.jneurosci.org as supplemental material), which were derived from adult mice. Dissected tissue was digested in $0.25 \%$ trypsin $/ 0.02 \%$ versene (adult tissue only) and triturated by repeated pipetting through a $1 \mathrm{ml}$ Rainin pipette tip. All cultures were grown on laminin-coated plastic or poly-D-lysine/laminin-coated glass. SVZ and cortical astrocytes were cultured in Dulbecco's modified Eagle's medium (DMEM) supplemented with 10\% fetal bovine serum (FBS), L-Glutamine ( $2 \mathrm{mM})$ and antibiotics/antimicotics. To allow neurogenesis to occur from SVZ astrocytes, cells were grown to confluence, then changed to a serum-free medium of Neurobasal-A/B27-A for $6 \mathrm{~d}$ (supplemental Fig. $11 B, E, H$, available at www.jneurosci.org as supplemental material). SVZ neuroblasts were purified by differential adhesion (Lim and Alvarez-Buylla, 1999): freshly dissociated SVZ cells were plated on laminin-coated plastic flasks in DMEM/10\% FBS and incubated overnight at $37^{\circ} \mathrm{C}$, allowing astrocytes to attach to the bottom, whereas neuroblasts are still unattached. By collecting the culture medium after this overnight incubation, we can obtain a cell suspension enriched for SVZ neuroblasts and depleted of astrocytes. Neuroblasts purified in this manner were then plated at $50000 \mathrm{cells} / \mathrm{cm}^{2}$ on a cortical astrocyte monolayer in Neurobasal-A/B27-A medium and cultured for $5 \mathrm{~d}$ (supplemental Fig. $11 C, F, I$, available at www.jneurosci.org as supplemental material). All cultures were fixed by aspirating culture medium and directly adding $4 \%$ PFA for $10 \mathrm{~min}$ at room temperature. BrdU was added to culture medium at a final dose of $10 \mu \mathrm{M} 1 \mathrm{~h}$ (SVZ astrocyte subconfluent cultures; supplemental Fig. 11A,D,G, available at www.jneurosci.org as supplemental material) or $12 \mathrm{~h}$ (SVZ neurogenic cultures; supplemental Fig. $11 \mathrm{~B}, E, H$, available at www.jneurosci.org as supplemental material) before fixing cells.

Dorsal root ganglia cultures. Whole dorsal root ganglia (DRG) were dissected from E12.5 wild-type mouse embryos and cultured as explants on glass slides coated with poly D-lysine and laminin. Culture medium consisted of F14 medium with insulin $(10 \mathrm{mg} / \mathrm{ml})$, transferrin $(5 \mu \mathrm{g} / \mathrm{ml})$, bovine serum albumin $(0.35 \% \mathrm{w} / \mathrm{v})$, progesterone $(60 \mathrm{ng} / \mathrm{ml})$, putrescine $(16 \mu \mathrm{g} / \mathrm{ml})$, sodium selenite $(38 \mathrm{ng} / \mathrm{ml})$, L-thyroxine $(400 \mathrm{ng} / \mathrm{ml})$ and tri-iodo thyronine $(314 \mathrm{ng} / \mathrm{ml})$. Medium was supplemented with BDNF $(0,10,50$ or $100 \mathrm{ng} / \mathrm{ml})$. Two days later, medium was replaced and cytosine arabinoside $(10 \mu \mathrm{M})$ and aphydicolin $(10 \mu \mathrm{g} / \mathrm{ml})$ were added to block cell proliferation. After being cultured for a total of $3 \mathrm{~d}$, cells were fixed $10 \mathrm{~min}$ in $4 \%$ PFA and processed for immunocytochemistry.

Surgical procedures. For all surgical procedures, mice were anesthetized with Avertin (adults) or on ice (newborns) and rats with Ketamine/ Xylazine, and their heads were immobilized on a stereotaxic apparatus. For adult mice and rats, buprenorphine was injected to minimize postsurgery pain. For AraC infusions, Ara-C (2\%, Sigma) in vehicle $(0.9 \%$ saline) or vehicle alone was infused onto the surface of the brain of adult CD-1 male mice (3 months) with a mini-osmotic pump (Alzet, model 1007D; flow rate $0.5 \mu \mathrm{l} / \mathrm{h}, 7 \mathrm{~d}$ pump) as previously described (Doetsch et al., 1999b). Cannulas were implanted onto the surface of the brain at anterior $0 \mathrm{~mm}$, lateral $1.1 \mathrm{~mm}$ relative to Bregma. This treatment produced no lesion on the ventricular cavities or in the SVZ. After $6 \mathrm{~d}$ of infusion, mice were killed immediately and cut on cryostat for analysis. For BDNF infusions, mini-osmotic pumps ( $0.5 \mu \mathrm{l} / \mathrm{h}, 14 \mathrm{~d}$ pumps, Alzet) were filled with $1 \mathrm{mg} / \mathrm{ml}$ BDNF in vehicle solution $(0.9 \%$ saline with $0.1 \%$ BSA) or vehicle alone. BDNF was a gift of Regeneron Pharmaceuticals. Pumps were then implanted onto the skull of CD-1 adult male mice (P90, $\sim 40 \mathrm{~g}$ weight) at $-0.2 \mathrm{~mm}$ anteroposterior and $0.95 \mathrm{~mm}$ lateral relative to Bregma; pump cannula was cut at $2.7 \mathrm{~mm}$ length so that it would penetrate the lateral ventricle. Pumps were also implanted onto the skull of adult male Sprague Dawley rats $(\sim 250 \mathrm{~g}$ weight $)$ at $0 \mathrm{~mm}$ anteroposterior and $1.6 \mathrm{~mm}$ lateral relative to Bregma; pump cannula was cut at $4.5 \mathrm{~mm}$ length so that it would penetrate the lateral ventricle. Accurate pump placement was visually confirmed for all animals after cryostat sectioning of the brains. For grafting experiments, we dissected and triturated the SVZ of postnatal day 1 (P1) TrkB:Tau-LacZ/GFP and wild-type/GFP mice, then grafted the cell suspensions into CD-1 adult mice using a stereotaxic apparatus (bilateral injections into the SVZ at 2 different coordinates: anterior $0.5 \mathrm{~mm}$, lateral $1.1 \mathrm{~mm}$, depth $1.7 \mathrm{~mm}$; anterior $1 \mathrm{~mm}$, lateral $1 \mathrm{~mm}$, depth $2.3 \mathrm{~mm}$ relative to Bregma and brain 
surface; 4 injections total) as previously described (Kohwi et al., 2005). Brains were processed and cut on vibratome for analysis.

Quantifications. To measure proliferation rates in the SVZ of neonatal TrkB-KO and WT mice (see Fig. $4 A, D$ ), we randomly selected 4 sections of anterior SVZ in each mouse to photograph the dorsal SVZ using a $20 \times$ objective. All $\mathrm{pH} 3{ }^{+}$cells within each picture were counted, totaling 412 (TrkB-WT) or 198 (TrkB-KO) pH3 ${ }^{+}$cells counted; $n=6 \mathrm{WT}$ and $4 \mathrm{KO}$ mice. We then measured SVZ cell density (total DAPI ${ }^{+}$cells/unit area) and the SVZ area counted in each animal to obtain the number of $\mathrm{pH} 3^{+}$ cells/thousand cells in the SVZ.

To measure apoptosis in the SVZ and OB of neonatal TrkB-KO and WT mice (see Fig. $4 B, C, E, F$ ), 5 sections of anterior SVZ or OB were selected at $30 \mu \mathrm{m}$ intervals and all TUNEL ${ }^{+}$cells in both SVZs or both OBs of each section were counted under a fluorescence microscope. A total of 108 (WT SVZ), 123 (KO SVZ), 173 (WT OB) and 228 (KO OB) TUNEL $^{+}$cells were counted; $n=6 \mathrm{WT}$ and $4 \mathrm{KO}$ mice. We then measured SVZ and OB cell density (total $\mathrm{DAPI}^{+}$cells/unit area) and the SVZ or OB area counted in each animal to obtain the number of TUNEL ${ }^{+}$ cells/thousand cells in these tissues.

To compare overall neurogenic levels in TrkB heterozygous and WT mice, we counted $\mathrm{BrdU}^{+}$cells in the $\mathrm{OB}$ of mice injected with $\mathrm{BrdU}$ at $\mathrm{P} 21$ and killed $15 \mathrm{~d}$ later at P36. For each mouse, 5 OB $50 \mu \mathrm{m}$ vibratome sections were selected for counting, both anterior and posterior to the anterior-most region of the accessory OB. Pictures covering all layers of the $\mathrm{OB}$ (but only a small part of the section) were taken of each section in all mice. We then counted all $\mathrm{BrdU}^{+}$cells in focus in each picture, totalling 1190 (WT) and 1486 (heterozygotes) cells; $n=3 \mathrm{WT}$ and 4 heterozygous mice.

To compare the survival of TrkB-KO and WT neurons in the OB (see Fig. $5 A, B, J), \mathrm{GFP}^{+} / \mathrm{BrdU}^{+}$grafted cells were counted. For each time point, $18-33$ pictures/mouse were taken randomly from multiple $\mathrm{OB}$ sections (50 $\mu \mathrm{m}$ vibratome sections) with a $40 \times$ objective, choosing similar regions in all mice (based on DAPI staining). A total of 693 (WT 15 d), 1099 (KO 15 d), 434 (WT 45 d), 966 (KO 45 d), 2555 (WT 180 d) or 2080 (KO $180 \mathrm{~d}) \mathrm{GFP}^{+}$cells were counted; $n=2-4$ mice/time point (see Fig. 5 legend for details).

To compare the proportions of $\mathrm{TH}^{+}$and $\mathrm{CalB}^{+}$cells among grafted periglomerular cells in the $\mathrm{OB}$ (see Fig. $5 C-F, K, L$ ), GFP ${ }^{+}$cells in the whole glomerular layer of $7-15$ sections/mouse (50 $\mu \mathrm{m}$ vibratome sections at $300 \mu \mathrm{m}$ intervals) were counted directly under a fluorescence microscope. GFP/TH or GFP/CalB double-labeled cells were identified by total overlap and identical contour of cellular labeling. A total of 667 (WT 45 d), 1071 (KO 45 d), 1306 (WT 180 d) or 828 (KO 180 d) [for TH analysis] and 1080 (WT $45 \mathrm{~d}$ ), 696 (KO $45 \mathrm{~d}$ ), 1532 (WT $180 \mathrm{~d}$ ) or 786 (KO $180 \mathrm{~d}$ ) [for CalB analysis] $\mathrm{GFP}^{+}$cells were counted; $n=3-5$ mice/ time point (see Fig. 5 legend for details).

To determine the proliferation rate of SVZ astrocytes cultured for $7 \mathrm{~d}$ in the presence or absence of BDNF (supplemental Fig. $11 A, D, G$, available at www.jneurosci.org as supplemental material), $\mathrm{BrdU}^{+}$cells were counted from nonoverlapping pictures taken with a $20 \times$ objective at fixed intervals across the middle of the culture wells. The number of pictures counted totaled 36/condition for one experiment ( 2 conditions: No BDNF and $100 \mathrm{ng} / \mathrm{ml}$ BDNF; 12 pictures/well, 3 replicates/experiment) and 24 for each of 2 additional experiments (12 pictures/well, 2 replicates/experiment). A total of 4038 or 2843 cells were counted (No $\mathrm{BDNF}$ and BDNF, respectively), $n=3$ experiments/group.

To determine the proliferation rate of neuroblasts generated in culture by a monolayer of SVZ astrocytes in the presence of varying amounts of BDNF (supplemental Fig. $11 B, E, H$, available at www.jneurosci.org as supplemental material), Tuj $1^{+}$and $\mathrm{Tuj}^{+} / \mathrm{BrdU}^{+}$cells were counted from nonoverlapping pictures taken with a $10 \times$ objective at fixed intervals across the middle of the culture wells. The number of pictures counted totaled 16/condition and 14/condition for two experiments (3 conditions: No BDNF, 10 and $100 \mathrm{ng} / \mathrm{ml}$ BDNF; 8 pictures/well and 7 pictures/well, 2 replicates/experiment) and 8/condition for each of 2 additional experiments ( 4 pictures/well, 2 replicates/experiment). A total of 5582, 6269 or 7446 cells were counted (No BDNF, 10 and $100 \mathrm{ng} / \mathrm{ml}$ $\mathrm{BDNF}$ respectively).

To determine the survival/proliferation of SVZ neuroblasts in the presence or absence of BDNF and with or without TrkB (supplemental Fig. 11C, F, I, available at www.jneurosci.org as supplemental material), $\mathrm{GFP}^{+} / \mathrm{Tuj} 1^{+}$cells were counted from pictures of cells cultured in each of these conditions. Nonoverlapping pictures were taken with a $10 \times$ objective at fixed intervals across the middle of the culture wells, but only the top half of each picture was counted because of the high numbers of cells (numbers presented are an extrapolation of cells/picture from those countings). The number of pictures counted totaled 18/condition (6 pictures/well, 3 replicates/experiment). A total of 2946 cells (TrkB-WT, No BDNF), 2179 cells (TrkB-KO, No BDNF), 2648 cells (TrkB-WT, 100 $\mathrm{ng} / \mathrm{ml} \mathrm{BDNF}$ ) or 2614 cells (TrkB-KO, $100 \mathrm{ng} / \mathrm{ml} \mathrm{BDNF}$ ) were counted, $n=2$ experiments/group.

To determine the proliferation rates in the SVZ of BDNF and vehicleinfused mice (see Fig. $6 C, E$ ), pH3 ${ }^{+}$cells were counted in $2810 \mu \mathrm{m}$ cryostat sections in each mouse, ipsilateral to pump side, at $50 \mu \mathrm{m}$ intervals (spanning a total of $1350 \mu \mathrm{m}$ ). Counted sections were taken from the anterior-most region of the lateral ventricle ( $1.2 \mathrm{~mm}$ rostral to Bregma) to the site of entry of the pump cannula into the ventricle $(0.2 \mathrm{~mm}$ caudal to Bregma) and the entire SVZ in each picture was counted under a fluorescence microscope. A total of 2414 or $1872 \mathrm{pH} 3^{+}$cells were counted (vehicle or BDNF-infused mice, respectively), $n=5$ mice/group.

To determine the apoptosis rates in the SVZ of BDNF and vehicleinfused rats, $\mathrm{TUNEL}^{+}$cells were counted in 24-36 $12 \mu \mathrm{m}$ cryostat sections in each rat, ipsilateral to pump side, at $60 \mu \mathrm{m}$ intervals (spanning a total of $1380-2100 \mu \mathrm{m}$ ). Counted sections were taken from the anteriormost region of the lateral ventricle (1.4-2.1 mm rostral to Bregma) to the site of entry of the pump cannula into the ventricle (Bregma level) and the entire SVZ in each picture was counted under a fluorescence microscope, excluding sections in which SVZ was significantly damaged by the cannula. A total of 424 or $239 \mathrm{TUNEL}^{+}$cells were counted (vehicle or BDNF-infused mice, respectively), $n=6$ rats for vehicle and 5 rats for $\mathrm{BDNF}$ group. We then estimated the total number of TUNEL ${ }^{+} \mathrm{SVZ}$ cells within the area sampled for quantification by multiplying the number of $\mathrm{TUNEL}^{+}$cells/section counted by the total number of sections collected within that area in each animal.

To determine the proliferation rates in the SVZ of BDNF and vehicleinfused rats, $\mathrm{pH}^{+}{ }^{+}$cells were counted in $2412 \mu \mathrm{m}$ cryostat sections in each rat, ipsilateral to pump side, at $60 \mu \mathrm{m}$ intervals (spanning a total of $1380 \mu \mathrm{m}$ ). Counted sections were taken from the anterior-most region of the lateral ventricle ( $1.4 \mathrm{~mm}$ rostral to Bregma) to the site of entry of the pump cannula into the ventricle (Bregma level) and the entire SVZ in each picture was counted under a fluorescence microscope, excluding sections in which SVZ was significantly damaged by the cannula. A total of 3276 or $2498 \mathrm{pH}^{+}$cells were counted (vehicle or BDNF-infused mice, respectively), $n=6$ rats/group.

To determine the number of Mash $1^{+}$cells in the SVZ of BDNF and vehicle-infused rats, we used a $20 \times$ objective to take 4 pictures of the dorsal SVZ of each rat analyzed, ipsilateral to pump side (each picture covers a field of $591 \times 444 \mu \mathrm{m}$ ). Pictures were taken at $\sim 360 \mu \mathrm{m}$ intervals, spanning the same region of the rostro-caudal axis analyzed for $\mathrm{pH} 3$ quantifications and all Mash1 ${ }^{+}$cells therein were counted. A total of

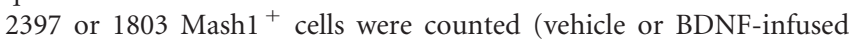
mice, respectively), $n=6$ rats/group.

To determine the number of new neurons added to the $\mathrm{OB}$ during the course of BDNF or vehicle infusions in mice (see Fig. $6 D, F$ ) and rats (see Fig. $8 C$ ), $\mathrm{BrdU}^{+}$cells were counted from pictures of $\mathrm{OB}$ sections. Three $\mathrm{OB}$ sections at $500 \mu \mathrm{m}$ (mice) or $1200 \mu \mathrm{m}$ (rats) intervals from each other were selected from the OB ipsilateral to the pump of each animal. Sections were considered of equivalent regions between animals because the location of the accessory OB (AOB) was used as a landmark, making sure the third section selected for each animal was immediately before (mice) or at (rats) the appearance of the AOB. For mice, a total of 6 nonoverlapping pictures were taken with a $10 \times$ objective for each $\mathrm{OB}$ section selected, covering $90-100 \%$ of the section (depending on section size). For rats, a total of 8 nonoverlapping pictures were taken with a $10 \times$ objective for each OB section selected, covering $80-90 \%$ of the section. All of the BrdU ${ }^{+}$cells in these pictures were counted. A total of 5278 or $5212 \mathrm{BrdU}^{+}$cells (vehicle or BDNF-infused mice, respectively) were counted, $n=5$ mice/group. A total of 12773 or $10491 \mathrm{BrdU}^{+}$cells 
(vehicle or BDNF-infused rats, respectively) were counted, $n=5$ rats for vehicle group and 6 rats for $\mathrm{BDNF}$ group. Colabeling and counting of BrdU and the lineage markers $\mathrm{HuC} / \mathrm{D}$, Iba1 and Olig2 was performed separately on each of the $3 \mathrm{OB} \mathrm{sec}$ tions/animal used for the total BrdU quantifications $(n=5$ mice/group or $n=2$ vehicle rats and 3 BDNF rats; in each case, the first section was used for $\mathrm{BrdU} / \mathrm{HuC} / \mathrm{D}$ labeling, the second for BrdU/Ibal and the third for BrdU/Olig2).

OB BrdU quantifications for the rat infusion experiment in which BrdU was injected only on experimental day 4 (supplemental Fig. 12C, available at www.jneurosci.org as supplemental material) were performed as described above for the first rat infusion experiment, with the exception that 7 nonoverlapping pictures, rather than 8 , were taken of each $\mathrm{OB}$ section used for quantification. A total of 9385 or 7046 BrdU $^{+}$cells (vehicle or BDNF-infused rats, respectively) were counted, $n=6$ rats for vehicle group and 5 rats for BDNF group.

\section{Results}

\section{RT-PCR characterization of} neurotrophins and their receptors in the SVZ

We used semiquantitative RT-PCR to characterize the expression of multiple neurotrophins (CNTF, GDNF, NGF, NT3, NT4, BDNF) and their receptors (CNTFR, gp130, GFR $\alpha 1$, Ret, p75, TrkA, TrkB, TrkC) (Table 1; see Fig. 1 legend for details) (for review, see Neet and Campenot, 2001) in the adult mouse SVZ (Fig. $1 A, B$ ). Because it is not possible to obtain RNA from the SVZ without some contamination from the adjacent striatum, we included in our analysis RNA collected from striatum close to the SVZ and compared expression levels between the two tissues. We found that TrkB is the most abundant neurotrophin receptor in SVZ samples (Fig. 1A). TrkB is also the only receptor whose expression is significantly enriched in SVZ when compared with striatum. This enrichment seems to be caused by high levels of expression of TrkB-TR isoform, because TrkB-FL was detected at lower levels and showed no enrichment in the SVZ. Other neurotrophin receptors, such as CNTFR and TrkC, were also detected in SVZ samples, but their expression level was very similar in striatal samples, which might have contributed to some of the SVZ signal. However, based on this analysis, we cannot discard possible roles for TrkC and CNTFR in the SVZ.

Neurotrophin expression levels in the SVZ were in general extremely low and none seemed to be enriched in the SVZ when compared with striatum (Fig. $1 B$ ). We looked at the expression of neurotrophins from the choroid plexus, which secretes many of the cerebral spinal fluid (CSF) components and is thus a possible distant source of neurotrophins for SVZ cells. As in the SVZ, most neurotrophins were detected at low levels, with the exception of the TrkB ligand NT4 (Fig. 1C).
Table 1. Expression of multiple neurotrophins and their receptors

\begin{tabular}{|c|c|c|}
\hline Gene & Forward primer & Reverse primer \\
\hline CNTFR & ATC ACC TTT GAC GAA TTC ACC A & ATG TAT TCC TTC CCT GCG TAG G \\
\hline gp130 & CTC ACA CGG AGT ACA CGC TGTC & CTC TTG GAA GGA TCA GGA ACA TTA G \\
\hline GFR $\alpha 1$ & GGA CAA TAC GTG TCT CAA AAA TGC & ATT ATC AGA AAG ACA GAG ATG TGT ACT GC \\
\hline Ret & GGC TGT CCC GAG ATG TTT ATG & GTA CAT TTC CTC GCT GCA GTT GT \\
\hline p75 & GAC CGG CTG CGC CTG & GGT AGT AGC CAT AGG AGC ATC GG \\
\hline TrkA & GGC CCG TTG CTC ATG GT & CCA GAC AGT TGC GTG TGGC \\
\hline $\operatorname{TrkB}$ & GAA TAA CGG AGA CTA CAC CCT GAT G & ACC ACA GAT GCA ATC ACC ACC \\
\hline TrkB-FL & TGG CGT CCC AAC ACT TTG T & CTT GCC GTA GGT GAA GAT CTCC \\
\hline TrkB-TR & GGA CTG CTG TTG CCT ATC CC & CAG CTC GCT TTT CAT TAG AGA GG \\
\hline TrkC & GAC TAT GTG GGC TCC GTG CT & GCT TCT GGA GTC CCG TGT AGA G \\
\hline CNTF & TGG CTT TCG CAG AGC AATC & GGA GGT TCT CTT GGA GTC GCT \\
\hline GDNF & CGC CCG CTG AAG ACC AC & AAA CGC ACC CCC GAT TTT \\
\hline$N G F$ & GCC AAG GAC GCA GCT TTC TAT A & CGG GTC TGC CCT GTC ACT \\
\hline NT3 & CGG ATG CCA TGG TTA CTT CTG & TGC CTC TGC TTT GGG CAG \\
\hline NT4 & GGC TGC TCT ACC GTG CCT TAT & CCA GGG TCC TCT GAT GTT AAA ATG \\
\hline BDNF & GGT CAC AGC GGC AGA TAA AAA G & TGA ATC GCC AGC CAA TTC TC \\
\hline
\end{tabular}
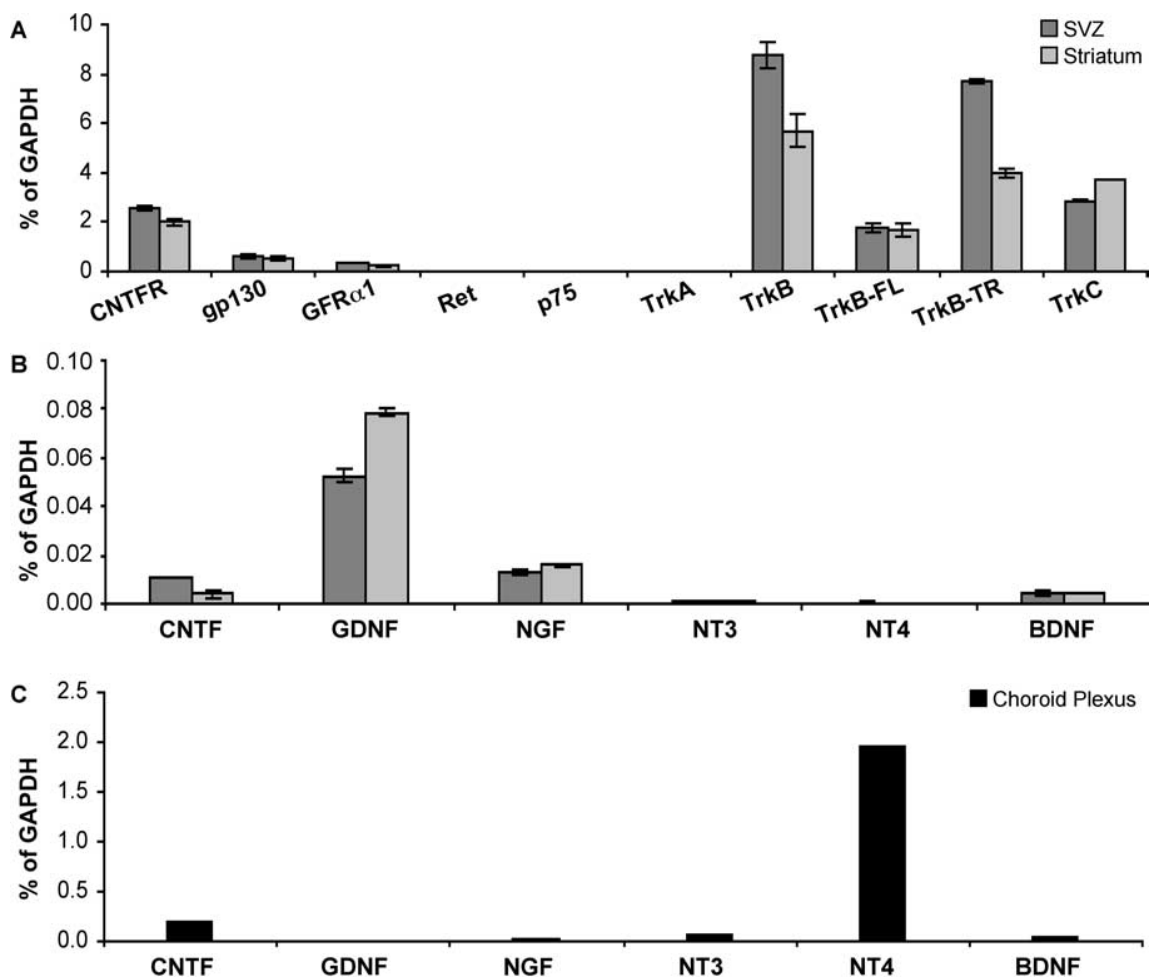

Figure 1. RT-PCR analysis of neurotrophin receptors and ligands. We used semiquantitative RT-PCR to determine the relative expression levels of multiple neurotrophins and their receptors in the adult mouse brain (CNTFR, gp130: receptors for CNTF; GFR $\alpha 1$, Ret: receptors for GDNF; p75: low affinity receptor for NGF, NT3, NT4, BDNF; TrkA: high affinity receptor for NGF; TrkB: high affinity receptor for NT4, BDNF; TrkB-FL and TrkB-TR: full-length and truncated isoforms of TrkB receptor; TrkC: high affinity receptor for NT3). $\boldsymbol{A}$, Neurotrophin receptor expression levels in SVZ and striatum. $\boldsymbol{B}$, Neurotrophin expression levels in SVZ and striatum. $\boldsymbol{C}$, neurotrophin expression levels in choroid plexus. All values are normalized to GAPDH expression and represent average \pm SEM. Data in $\boldsymbol{A}, \boldsymbol{B}$, represent average from two experiments, pooling RNA from 8 adult mice/experiment; data in $\boldsymbol{C}$, represents RNA of 16 adult mice pooled in one experiment.

Based on these results as well as those of previous publications (Zigova et al., 1998; Benraiss et al., 2001), the neurotrophin signaling molecules most likely to play a role in adult SVZ neurogenesis are the receptor TrkB and its ligands. Therefore, we decided to further characterize these molecules in the context of SVZ neurogenesis.

\section{Expression of BDNF and TrkB in SVZ}

Consistent with the results presented in Figure 1, in situ hybridization revealed very low levels of BDNF mRNA in the adult 

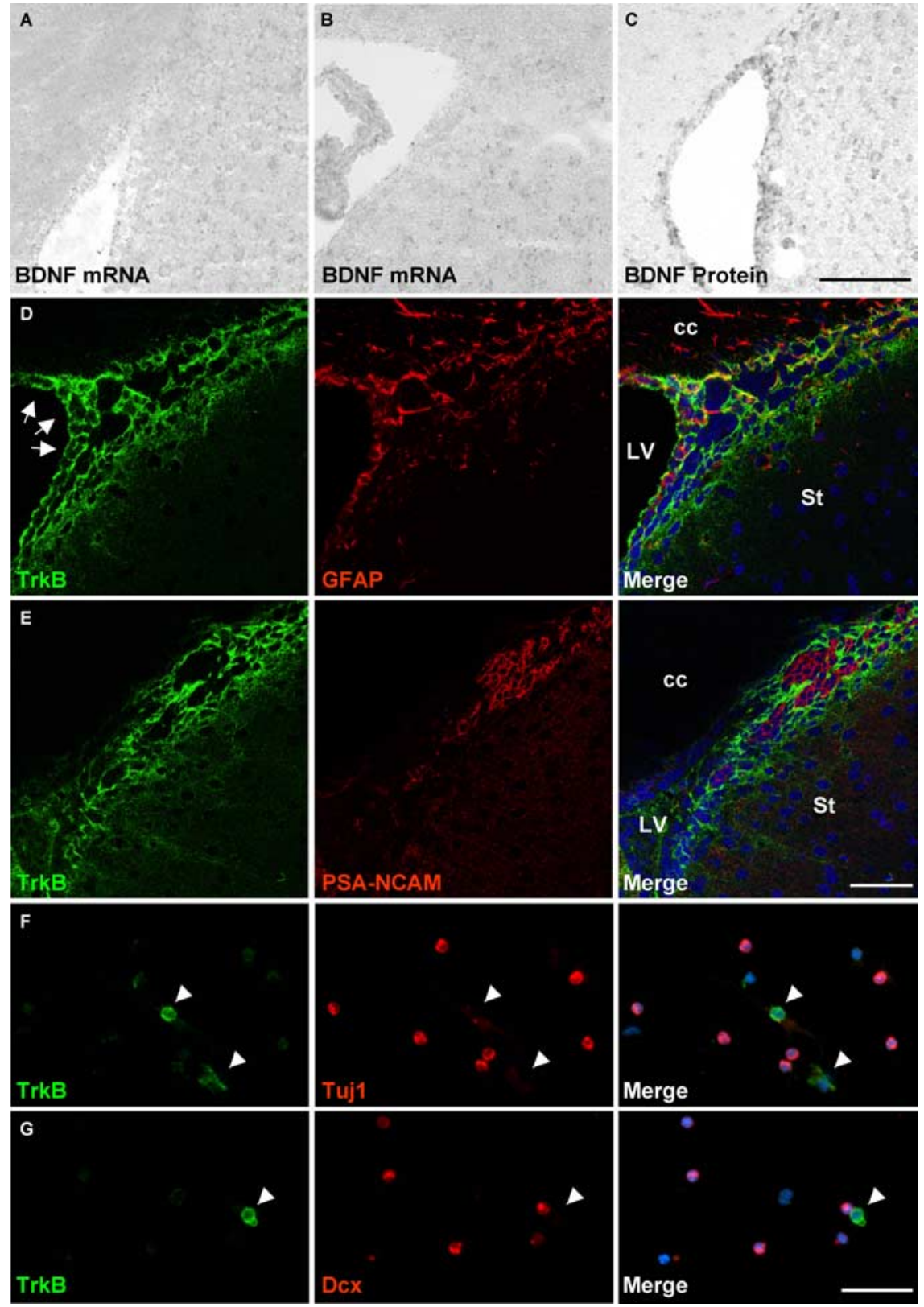

Figure 2. Expression analysis of BDNF and TrkB in the mouse SVZ. $A, B$, In situ hybridization detects very low levels of BDNF mRNA at all levels of the adult SVZ ( $\boldsymbol{A}$, anterior SVZ; $\boldsymbol{B}$, medial/posterior SVZ). $\boldsymbol{C}$, Immunostaining detection of BDNF protein in the adult SVZ. D, $\boldsymbol{E}$, Confocal images of TrkB immunostaining in adult mouse SVZ. D, TrkB (green) colocalizes with the astrocyte marker GFAP (red); arrows: ependymal cells lining the ventricular wall also express TrkB. $\boldsymbol{E}$, TrkB (green) does not colocalize with the neuroblast marker PSA-NCAM (red). $\boldsymbol{F}, \mathbf{G}$, Immunostaining for TrkB receptor (green) on acutely dissociated neonatal SVZ cells confirms that SVZ neuroblasts, detected with Tuj $1\left(\boldsymbol{F}\right.$, red) or Dcx antibodies ( $\boldsymbol{G}$, red) do not express TrkB (arrowheads: TrkB ${ }^{+}$cells isolated from SVZ are negative for Tuj1 and Dcx). Scale bars: $(\boldsymbol{A}-\boldsymbol{C}), 100 \mu \mathrm{m} ;(\boldsymbol{D}, \boldsymbol{E}), 50 \mu \mathrm{m} ;(\boldsymbol{F}, \boldsymbol{G}), 30 \mu \mathrm{m}$. cc, corpus callosum; LV lateral ventricle; St, striatum.

mouse SVZ (Fig. 2A,B). Nonetheless, low levels of BDNF protein were detected in the SVZ, suggesting that cells in this neurogenic niche may be exposed to endogenous BDNF (Fig. 2C).

We then analyzed the expression of TrkB in the SVZ by immunohistochemistry and confocal microscopy, using a TrkBspecific antibody (Fig. 2D-G) as well as a TrkB:Tau-LacZ reporter mouse line (supplemental Fig. 1, available at www.jneurosci. org as supplemental material) (see Materials and Methods for details). Both methods confirmed abundant expression of TrkB in the adult SVZ. TrkB is strongly expressed in ependymal cells (Fig. $2 D$; supplemental Fig. $1 B$, available at www.jneurosci.org as supplemental material). Using cell typespecific markers, we could also detect TrkB in many $\mathrm{GFAP}^{+}$astrocytic type B cells in the SVZ (Fig. 2D; supplemental Fig. $1 B$, available at www.jneurosci.org as supplemental material). To label slowly dividing cells in the SVZ (Morshead et al., 1994; Chiasson et al., 1999; Doetsch et al., 1999b), we administered BrdU to adult mice for 1 week, followed by a 3 week chase period before sacrificing the mice. Many of the BrdU-retaining cells in the SVZ, which are thought to include locally differentiated cells as well as stem cells, expressed the reporter product $\beta$-Gal (supplemental Fig. $1 A$, available at www.jneurosci.org as supplemental material), thus raising the possibility that stem cells themselves are $\mathrm{TrkB}^{+}$. We found that TrkB does not colocalize with PSA-NCAM, a marker for migrating neuroblasts produced in the SVZ (Fig. 2 E; supplemental Fig. $1 D$, available at www.jneurosci.org as supplemental material). $\beta$-Gal colocalization with GFAP and not with PSA-NCAM was also observed in the adult mouse RMS (supplemental Fig. 1C,E, available at www. jneurosci.org as supplemental material). To confirm this finding, we immunolabeled acutely dissociated SVZ cells from early postnatal pups with an antibody specific for the extracellular domain of TrkB. The SVZ cells were fixed and stained $1 \mathrm{~h}$ after dissociating the tissue, so that the staining would more accurately reflect the in vivo expression of TrkB. As a control for possible nonspecific labeling by the antibody used, we processed cells isolated from TrkB knock-out (TrkB-KO) and wild-type (WT) littermates in parallel. Nearly all TrkB ${ }^{+}$cells were negative for the neuroblast markers Tuj1 (Fig. 2F, 68 of 70 cells) and Dcx (Fig. 2G, 36 of 38 cells). We also used two additional anti-TrkB antibodies to characterize TrkB expression in SVZ sections, both of which gave results consistent with the data mentioned above (supplemental Fig. 2A-E, available at www.jneurosci.org as supplemental material; Table 2). Furthermore, tissue from adult TrkB:Tau-LacZ reporter mice was stained by $\beta$-Gal enzymatic reaction and analyzed at the electron microscope. Again, ependymal cells and type B cells were heavily labeled with $\beta$-Gal precipitates, whereas neuroblasts were not (supplemental Fig. 3, available at www. jneurosci.org as supplemental material).

These results were unexpected because recent publications have reported TrkB expression in vivo on SVZ neuroblasts and not on astrocytes (Chiaramello et al., 2007; Bath et al., 2008). However, the staining obtained with the antibody used by Chiaramello et al. (2007) (supplemental Fig. $2 F, G$ ) is opposite to that of the 3 other TrkB antibodies we used in this study (Fig. 2D-G; supplemental Fig. $2 A-E$, available at www.jneurosci.org as sup- 
plemental material). We confirmed the specificity of 2 of these antibodies by Western blot and immunohistochemistry (Fig. $3 G$; supplemental Fig. $2 C$, available at www.jneurosci.org as supplemental material), whereas the antibody used in Chiaramello et al. (2007) did not reveal any bands (supplemental Fig. $2 \mathrm{H}$, available at www. jneurosci.org as supplemental material). The anti-phosphorylated TrkB (pTrkB) antibody used by Bath et al. (2008) appears to detect phosphorylated TrkB receptor in Western blots from cultured E18 rat hippocampal neurons stimulated with 50 $\mathrm{ng} / \mathrm{ml} \mathrm{BDNF}$ for $10 \mathrm{~min}$ (supplemental Fig. $4 N$, available at www.jneurosci.org as supplemental material). However, in untreated adult mouse SVZ extracts, this antibody seems to detect another, unknown antigen: pTrkB antibody strongly bound to one or more proteins of $\sim 80 \mathrm{kDa}$, whereas no bands were visible at the weights of known TrkB isoforms (95 or $145 \mathrm{kDa}$, supplemental Fig. $4 M$, available at www.jneurosci.org as supplemental material). Additionally, this antibody labeled TrkB-KO cells that were grafted into a WT brain (supplemental Fig. 5, available at www.jneurosci.org as supplemental material).

\section{Cells in SVZ and RMS express the truncated isoform of TrkB}

The TrkB receptor exists in two different isoforms, full-length (TrkB-FL) and truncated (TrkB-TR), generated by alternative splicing (Klein et al., 1989, 1990; Middlemas et al., 1991). TrkB-FL is responsible for most known effects of TrkB activation, whereas TrkB-TR functions are poorly understood. These isoforms differ greatly in their intracellular signaling ability because of the absence of the intracellular kinase domains in TrkB-TR. Because we could not discriminate between these two isoforms by immunohistochemistry alone, we performed in situ hybridization with a probe specific for TrkB-FL as well as with one that recognizes all $\mathrm{TrkB}$ isoforms (TrkB-all). Consistent with all of the data described above, TrkB mRNA in the adult mouse SVZ was abundant in some cells but undetectable in others. Typically, $\mathrm{TrkB}^{-a l l}{ }^{+}$cells were distributed in ringlike patterns surrounding unlabeled cells (Fig. 3A). Such staining likely reflects the known distribution of SVZ type B cells surrounding chains of migrating neuroblasts (Jankovski and Sotelo, 1996; Lois et al., 1996; Peretto et al., 1997). TrkB was also strongly expressed in the adult mouse RMS, exhibiting a pattern very similar to that of the SVZ (Fig. 3B). Strikingly, the expression of TrkB-FL was radically different, because we did not detect any TrkB-FL in either

TrkB-FL
Table 2. Antibodies used for immunohistochemistry

\begin{tabular}{|c|c|c|c|c|}
\hline Antigen & Sp. & Dilution & Source & Catalog\# \\
\hline$\beta$ III Tubulin & Ms & $1: 500$ & Covance, Berkeley, CA & MMS-435P \\
\hline$\beta$-Actin & $\mathrm{Rb}$ & $1: 1000$ & AbCam, Cambridge, MA & ab8227 \\
\hline BDNF & $\mathrm{Rb}$ & $1: 100$ & Santa Cruz Biotechnology, Santa Cruz, CA & sc-546 \\
\hline$\beta-G a l$ & Ms & $1: 500$ & Promega, Madison, WI & $\mathrm{Z3781}$ \\
\hline BrdU & Rt & $1: 100$ & AbCam, Cambridge, MA & ab6326 \\
\hline Calbindin & Ms & 1:1000 & Swant, Bellinzona, Switzerland & 300 \\
\hline GFAP & Ms & $1: 500$ & Chemicon, Temecula, CA & MAB3402 \\
\hline GFP & $\mathrm{Ch}$ & $1: 500$ & Aves Labs, Tigard, OR & GFP-1020 \\
\hline $\mathrm{HuC} / \mathrm{D}$ & Ms & $1: 10$ & Molecular Probes, Eugene, OR & MAB16A11 \\
\hline Mash1 & Ms & $1: 150$ & BD Pharmingen, San Jose, CA & 556604 \\
\hline p75 (extra-c.) & $\mathrm{Rb}$ & $1: 2000$ & Louis Reichardt (Weskamp and Reichardt, 1991) & \\
\hline p75 (intra-c.) & $\mathrm{Rb}$ & 1:1000 & Promega, Madison, WI & G3231 \\
\hline p75 (extra-c.) & Ms & $1: 100$ & Chemicon, Temecula, CA & MAB365 \\
\hline p75 (extra-c.) & $\mathrm{Rb}$ & $1: 500$ & Moses Chao (9651) (Huber and Chao, 1995) & \\
\hline p75 (intra-c.) & $\mathrm{Rb}$ & $1: 500$ & Moses Chao (9992) & \\
\hline $\mathrm{pH} 3$ & $\mathrm{Rb}$ & $1: 200$ & Upstate, Lake Placid, NY & $06-570$ \\
\hline PSA-NCAM & Ms & $1: 500$ & AbCys, Paris, France & $\mathrm{AbC0019}$ \\
\hline pTrkB & $\mathrm{Rb}$ & 1:200/1:1000 & Moses Chao (Bath et al., 2008) & \\
\hline TrkB & $\mathrm{Rb}$ & $1: 200 / 1: 750$ & Upstate, Lake Placid, NY & $07-225$ \\
\hline TrkB-TR & $\mathrm{Rb}$ & $1: 200$ & Santa Cruz Biotechnology, Santa Cruz, CA & sc-119 \\
\hline TrkB & $\mathrm{Rb}$ & $1: 200$ & Chemicon, Temecula, CA & AB9872 \\
\hline TrkB & $\mathrm{Rb}$ & $1: 200 / 1: 750$ & Chemicon, Temecula, CA & AB5372 \\
\hline TH & $\mathrm{Rb}$ & $1: 500$ & PelFreez, Rogers, AR & P40101 \\
\hline
\end{tabular}

Whenever different dilutions were used for immunohistochemistry and Western blot, both dilutions are presented in that order. Sp., species in which antibody was raised; $M$ s, mouse; $R$ t, rat; $R b$, rabbit; Ch, chicken; extra-c, extracellular; intra-c, intracellular.
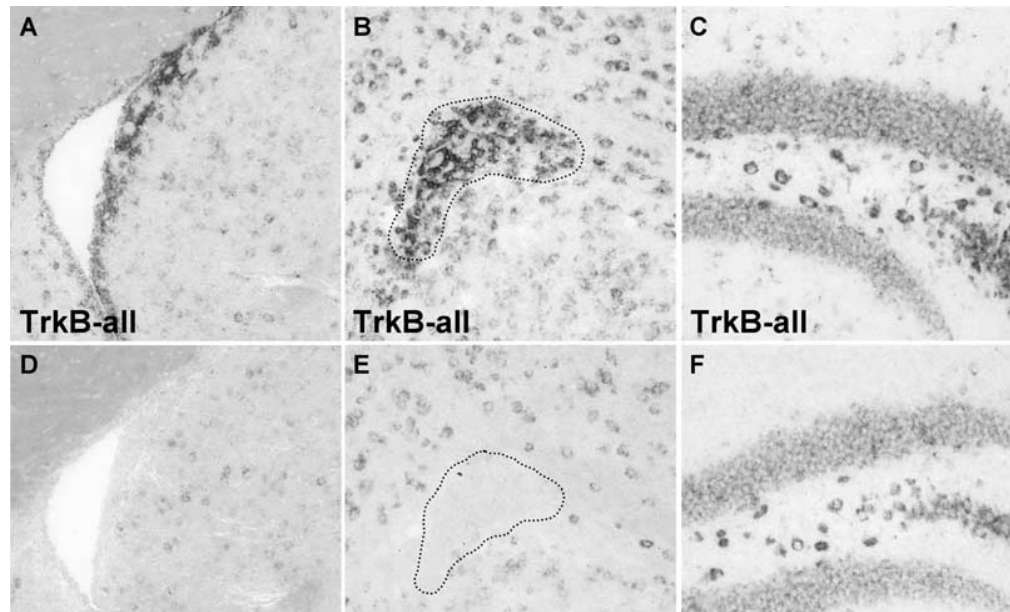

$\mathbf{F}$

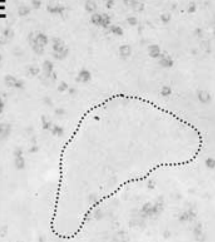

TrkB-FL
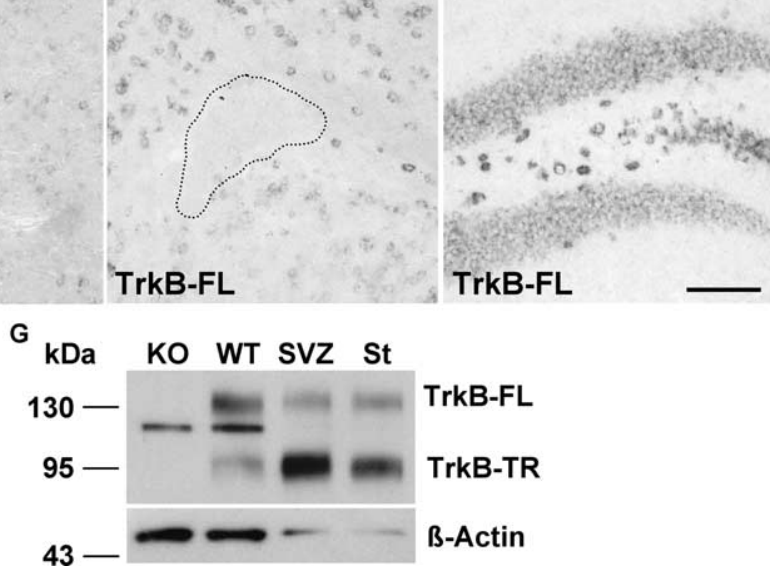

Figure 3. Expression of TrkB isoforms in the adult mouse SVZ. $\boldsymbol{A}-\boldsymbol{C}$, In situ hybridization to detect all is oforms of TrkB (TrkB-all) shows strong staining in the SVZ $(\boldsymbol{A}), \operatorname{RMS}(\boldsymbol{B})$ and hippocampal dentate gyrus $(\boldsymbol{C})$. $\boldsymbol{D}-\boldsymbol{F}$, In situ hybridization to specifically detect the full-length isoform of TrkB (TrkB-FL) shows that SVZ (D) and RMS (E) cells do not express this isoform, although hippocampal cells $(\boldsymbol{F})$ do. G, Western blot for TrkB shows that the predominant isoform in the SVZ is TrkB-TR at the protein level as well. Striatum protein was run for comparison and samples from TrkB-KO and WT whole brain (collected at P1) were used as controls; all samples were probed for $\beta$-Actin as loading control. Scale bar, $100 \mu \mathrm{m}$. Dashed line, outline of RMS.

the SVZ or RMS (Fig. 3D,E). We found at best 1-2 TrkB-FL ${ }^{+}$ cells/SVZ section, contrasting with an abundance of TrkB ${ }^{+}$cells when using the TrkB-all probe. Conversely, in other regions, such as the striatum (Fig. $3 A, D$ ) and hippocampus (Fig. $3 C, F$ ), we 

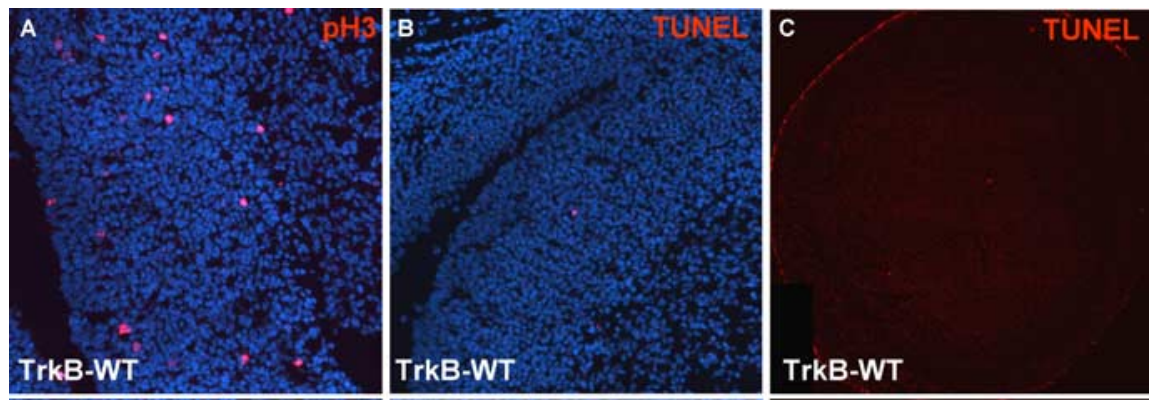

jneurosci.org as supplemental material). Therefore, eliminating the majority of type $\mathrm{C}$ cells and neuroblasts from the SVZ does not affect the expression of TrkB isoforms in this region. This result confirms that type $B$ and ependymal cells are the main source of TrkB in the adult mouse SVZ and suggests that, even when challenged to repopulate the SVZ, these cells express only the truncated isoform of TrkB.
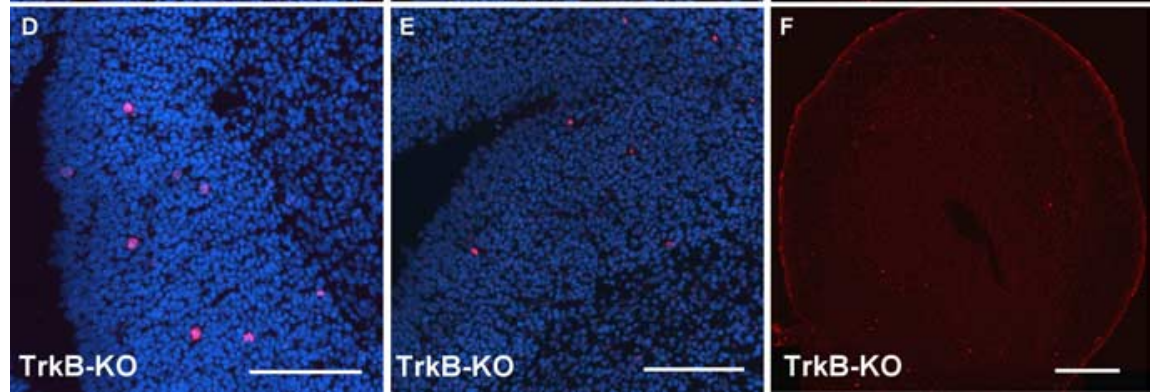

Figure 4. In vivo consequences of TrkB-KO. PO mice were stained in the SVZ and $\mathrm{OB}$ for phosphorylated histone $\mathrm{H3}(\mathrm{pH} 3$ ) and TUNEL to detect proliferating and apoptotic cells, respectively. $A, D, p H 3$ immunostaining (red) in SVZ of TrkB-WT $(\boldsymbol{A})$ and TrkB-KO $(\boldsymbol{D})$ mice. $\boldsymbol{B}, \boldsymbol{E}$, TUNEL (red) in SVZ of TrkB-WT $(\boldsymbol{B})$ and TrkB-KO $(\boldsymbol{E})$ mice. $\boldsymbol{C}, \boldsymbol{F}$, TUNEL (red) in OB of TrkB-WT ( $\boldsymbol{C}$ ) and TrkB-KO $(\boldsymbol{F})$ mice. Blue: DAPI (all panels). Scale bars: $(\boldsymbol{A}, \boldsymbol{D} ; \boldsymbol{B}, \boldsymbol{E}), 100 \mu \mathrm{m} ;(\boldsymbol{C}, \boldsymbol{F}), 1 \mathrm{~mm}$.

noticed no major difference between the expression patterns detected by TrkB-all and TrkB-FL probes, confirming that the difference found in the SVZ and RMS is not caused by an inability of the TrkB-FL probe to detect mRNA transcripts.

To corroborate this finding at the protein level, we characterized TrkB expression by Western blot in SVZ and striatal samples from adult CD1 mice, which allowed us to distinguish TrkB-FL and TrkB-TR isoforms by molecular weight $(145 \mathrm{kDa}$ and 95 $\mathrm{kDa}$, respectively). As predicted by the in situ hybridization data, the great majority of TrkB protein detected in SVZ samples was of the truncated isoform (Fig. $3 G$ ). A light band of TrkB-FL protein was detected in SVZ samples. This band may come from the inevitable contamination of SVZ samples with striatal tissue, where TrkB-FL was detected by in situ hybridization as well as by Western blot. Based on both mRNA localization and protein analysis, we conclude that the bulk of the TrkB found in the SVZ and RMS consists of the truncated isoform of the receptor. Consistently, we detected numerous $\mathrm{TrkB}_{-} \mathrm{TR}^{+}$cells in adult SVZ sections using an antibody specific to this receptor isoform (supplemental Fig. $2 A, B$, available at www.jneurosci.org as supplemental material).

It was possible that the low levels of TrkB-FL in the SVZ were the result of a low level of stem cell proliferation under normal conditions. We therefore decided to characterize the expression of TrkB-TR and TrkB-FL in the SVZ after infusing the brain with the antimitotic drug cytosine- $\beta$-D-arabinofuranoside (AraC). This treatment eliminates rapidly proliferating cell types from the SVZ (type C cells and neuroblasts), whereas many type B cells survive and ependymal cells are largely unaffected. After termination of AraC treatment, SVZ type B cells become activated and regenerate the neurogenic niche (Doetsch et al., 1999a). Using a microosmotic pump, we infused AraC unilaterally onto the surface of the brain of adult mice for $6 \mathrm{~d}$ and killed the mice immediately thereafter. We found that TrkB receptor was still detected at high levels in the SVZ with the TrkB-all in situ probe but not with the TrkB-FL probe (supplemental Fig. 6C,E, available at www. TrkB-KO mice (Fig. $4 A, D ; 7.8$ versus 10.4

\section{Neurons from TrkB-KO grafts survive,} mature, and integrate in the $\mathrm{OB}$

The above results show that TrkB-TR is expressed in the SVZ and RMS (Figs. $1 A$, 2D-G, 3; supplemental Figs. 1-3, available at www.jneurosci.org as supplemental material). We used TrkB-KO mice to determine whether this signaling pathway is required for SVZ neurogenesis. Because these mice do not survive beyond $1-3 \mathrm{~d}$ after birth, we performed our analysis on newborn, postnatal day 0 (P0) brains. We found that proliferation, as measured by phosphorylated histone $\mathrm{H} 3$ ( $\mathrm{pH} 3$ ) labeling, is reduced by $25 \%$ in the SVZ of $\mathrm{pH} 3$ cells $/ 10^{3}$ cells in WT vs TrkB-KO mice; SEM $=0.6$ for both groups; $p=0.019$ by Student's $t$ test). Apoptosis in TrkB-KO mice, as measured by TUNEL, is $87 \%$ higher in the SVZ (Fig. $4 B, E ; 376$ vs 701 TUNEL $^{+}$cells $/ 10^{6}$ cells in WT vs TrkB-KO mice; $\mathrm{SEM}=77$ vs 61 respectively; $p=0.016)$ and $74 \%$ higher in the OB (Fig. 4C,F; 248 vs 432 TUNEL $^{+}$cells $/ 10^{6}$ cells in WT vs TrkB-KO mice; SEM $=11$ vs 52 respectively; $p=0.003)$. To determine whether these defects in proliferation and survival result in fewer neurons added to the OB, we labeled a cohort of cells in TrkB heterozygous and WT littermates by injecting BrdU at P21 and killing the mice $15 \mathrm{~d}$ later. Consistent with the results described above, we detected a statistically not significant decrease in $\mathrm{BrdU}^{+}$cells in the $\mathrm{OB}$ of TrkB heterozygotes $(14.2 \%$ decrease, $p=0.098, n=3 \mathrm{WT}$ and 4 heterozygous mice). However, both homozygous and heterozygous TrkB mutant mice have various other defects unrelated with the SVZ, leading to death $(\operatorname{TrkB}-\mathrm{KO})$ or obesity $\left(\mathrm{TrkB}^{+/-}\right)$. Additionally, TrkB-KO mice have elevated levels of apoptosis in several other brain regions (Minichiello and Klein, 1996; Alcantara et al., 1997; Xu et al., 2000b). It is thus difficult to determine whether the results in the SVZ are directly caused by loss of TrkB or indirectly by some of these other defects.

To circumvent the short postnatal survival of TrkB-KO mice and to avoid any indirect effects caused by the absence of TrkB throughout development, we homotopically grafted SVZ cells from TrkB-KO and WT mice into the SVZ of WT adult mice. Donor cells were labeled by a $\beta$-Actin:GFP transgene and were collected from P1 pups, before TrkB deficiency becomes lethal. We then waited 15, 45 or $180 \mathrm{~d}$ and assessed the survival and maturation of the grafted cells (Fig. $5 G$ ). The total number of $\mathrm{GFP}^{+}$cells in the granular cell layer (GCL) of recipient mice increased significantly between 15 and $180 \mathrm{~d}$ in both TrkB-WT and TrkB-KO grafts (Fig. 5I) and we found numerous $\mathrm{GFP}^{+}$cells in all layers of the $\mathrm{OB}$. To determine the survival rate of a defined cohort of cells, grafted mice were given BrdU in the drinking water for the first $3 \mathrm{~d}$ after surgery. We then counted the propor- 


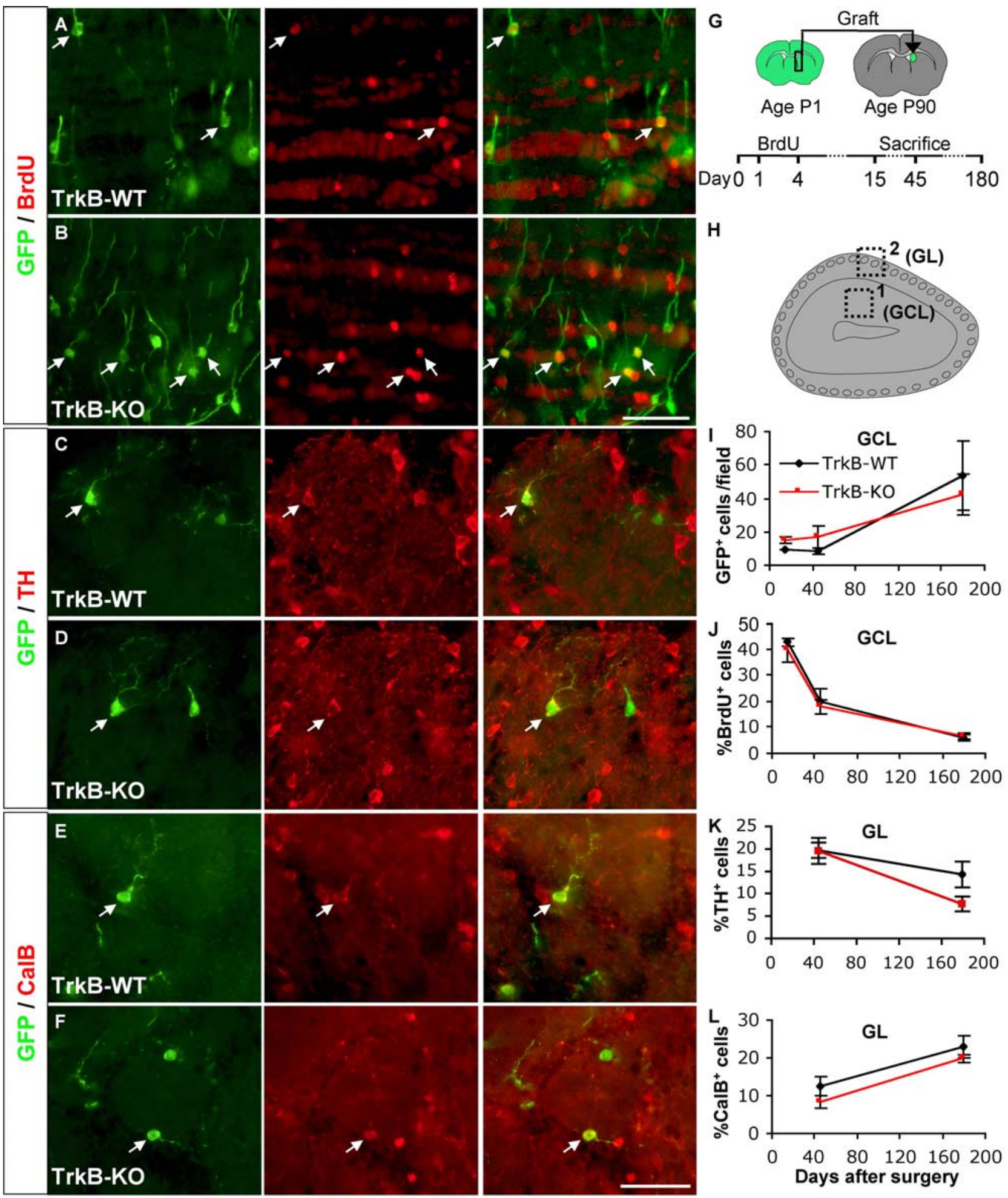

Figure 5. Grafted TrkB-KO cells can survive and mature in OB. $\beta$-actin:GFP ${ }^{+}$cells from SVZ of TrkB-WT or TrkB-KO P1 mice were grafted into the SVZ of WT, P90 mice; GFP ${ }^{+}$cells were then analyzed in the $0 B 15,45$ and $180 \mathrm{~d}$ after surgery; $B r d U$ was administered during the first $3 \mathrm{~d}$ after surgery. $A, B, G F P / B r d U$ (green/red) staining in the granular cell layer (GCL) of the $0 B$ of mice grafted with TrkB-WT (A) or TrkB-KO (B) cells. C, D, GFP/TH (green/red) staining in the glomerular layer (GL) of the OB of mice grafted with TrkB-WT (C) or TrkB-KO (D) cells. E, F, GFP/CalB (green/red) staining in the GL of mice grafted with TrkB-WT $(\boldsymbol{E})$ or TrkB-KO $(\boldsymbol{F})$ cells. $\mathbf{G}$, Experimental design. $\boldsymbol{H}$, Diagram of a coronal section of OB (dorsal to the left), showing general location from which data were collected (box 1: origin of data in $A, B, I, J$; box 2: origin of data in $C-F, K, L)$. $I$, Quantification of all GFP ${ }^{+}$cells/field (field $=435 \times 330 \mu \mathrm{m}$ ) in GCL of OB, showing increase in both TrkB-WT and TrkB-K0 cells throughout entire experiment; $n=3$ ( $15 \mathrm{dgraft}), n=2$ ( $45 \mathrm{~d}$ graft), $n=2$ (180 d graft). J, Quantification of the proportion of grafted cells labeled with BrdU in GCL of 0B, showing identical dynamics for TrkB-WT and TrkB-KO cells; $n=3$ (15 d graft), $n=4$ (45 d graft), $n=2$ (180 d graft). $K$, Proportion of grafted cells expressing TH protein in GL of 0B: there is a sharper drop in $\mathrm{TH}^{+}$cells among TrkB-KO cells than among TrkB-WT cells between 45 and $180 \mathrm{~d}$ after surgery; $n=4$ (all time points except $45 \mathrm{~d}$ TrkB-WT, for which $n=3$, and $180 \mathrm{~d}$ TrkB-K0, for which $n=$ 5). L, Proportion of grafted cells expressing CalB protein in GL of OB: both TrkB-WT and TrkB-KO grafted cells increase between 45 and $180 \mathrm{~d}$ after surgery; $n=4$ (all time points except $45 \mathrm{~d}$ TrkB-KO, for which $n=3$ ). All values represent average \pm SEM. All images shown were taken at 45 -day graft survival. Arrows indicate double-labeled cells. TH: tyrosine hydroxylase; CalB: Calbindin. Scale bars: $(\boldsymbol{A}, \boldsymbol{B}), 100 \mu \mathrm{m} ;(\boldsymbol{C}-\boldsymbol{F}), 50 \mu \mathrm{m}$ 
tion of $\mathrm{BrdU}^{+}$cells among all $\mathrm{GFP}^{+}$cells in the GCL. Grafted TrkB-WT and TrkB-KO cells had indistinguishable proportions of $\mathrm{BrdU}^{+}$cells at all time points analyzed, both undergoing a $\sim 50 \%$ decline between 15 and $45 \mathrm{~d}$, followed by a more gradual loss after $45 \mathrm{~d}$ (Fig. $5 \mathrm{~J}$ ). Such a behavior is identical to the population dynamics described by Petreanu and Alvarez-Buylla (2002) for new neurons in the adult WT GCL. These results show that TrkB-WT and TrkB-KO interneurons face similar survival challenges in the OB. The accumulation of $\mathrm{GFP}^{+}$neurons in the $\mathrm{OB}$ (Fig. $5 I$ ), together with the presence of $\mathrm{GFP}^{+}$cells in the RMS even $180 \mathrm{~d}$ after the graft (supplemental Fig. $7 A, B$, available at www.jneurosci.org as supplemental material), also show that both TrkB-WT and TrkB-KO stem cells can continuously give rise to new neurons.

TrkB may be involved in the maturation of OB interneurons rather than their survival. To address this possibility, we counted the proportion of grafted cells that express tyrosine hydroxylase $(\mathrm{TH})$ or Calbindin (CalB) in the glomerular layer (GL). TH is the rate-limiting enzyme in the synthesis of the neurotransmitter dopamine and CalB is a neuron-specific $\mathrm{Ca}^{2+}$-binding protein. These molecules are expressed in distinct subpopulations of mature OB periglomerular neurons (Rogers, 1992; Kosaka et al., $1995)$. Fourty five days after the graft, $\sim 19 \%$ of $\mathrm{GFP}^{+}$periglomerular cells were $\mathrm{TH}^{+}$, irrespectively of their genotype (Fig. $5 K)$. CalB expression was slightly lower at $45 \mathrm{~d}$ ( $8.5 \%$ of TrkB-KO cells were $\mathrm{CalB}^{+}$, compared with $12.7 \%$ among TrkB-WT cells; Fig. $5 L$ ). However, this difference was not statistically significant ( $p=0.27$ by Student's $t$ test). At $180 \mathrm{~d}$, TH expression dropped to $14.1 \%$ in TrkB-WT cells and to $7.5 \%$ in TrkB-KO cells (Fig. $5 K$, $p=0.07$ by Student's $t$ test, not statistically significant). However, CalB expression increased to $22.9 \%$ and $19.9 \%$ among TrkB-WT and TrkB-KO grafted cells, respectively (Fig. 5L). The observation that the proportion of $\mathrm{TH}$ expression among grafted cells drops between 45 and $180 \mathrm{~d}$ whereas that of CalB continues to rise is consistent with others' observations (Kohwi et al., 2007) and probably reflects differences in the maturation time and/or turnover rate for these different cell types.

$\mathrm{TH}$ and $\mathrm{CalB}$ expression are dependent on synaptic activity (Baker et al., 1983; Philpot et al., 1997). The detection of TH and CalB, as well as of dendritic spines in TrkB-KO neurons (supplemental Fig. $7 C, D$, available at www.jneurosci.org as supplemental material) suggests that at least some of these cells are capable of functionally integrating into the OB circuitry. Overall, the results of our grafting experiment indicate that TrkB is not essential for the production, migration and differentiation of new $\mathrm{OB}$ neurons, although it may be required for the maturation and longterm survival of specific cell types.

\section{BDNF does not promote mouse neurogenesis}

Although TrkB may not be required for postnatal SVZ neurogenesis, it was possible that BDNF could act through a different receptor to regulate neuron production from the SVZ. To test this hypothesis, we used microosmotic pumps to infuse a concentrated solution of BDNF $(1 \mathrm{mg} / \mathrm{ml})$ or vehicle $(0.9 \% \mathrm{NaCl}$ with $0.1 \%$ bovine serum albumin) into the lateral ventricle of WT adult mice for $14 \mathrm{~d}$. BDNF delivered intraventricularly has previously been shown to penetrate the brain parenchyma deep enough to reach cells in the SVZ (Yan et al., 1994; Anderson et al., 1995).

To determine the proliferation rate in the SVZ, we immunostained for $\mathrm{pH} 3$ and counted the number of $\mathrm{pH}^{+}$cells. We found that BDNF-infused mice had $22.5 \%$ fewer $\mathrm{pH} 3^{+}$cells in the SVZ ipsilateral to the pump implant when compared with vehicle-infused mice (Fig. 6C,E; 17.2 vs $13.4 \mathrm{pH} 3^{+}$cells/section in vehicle vs $\mathrm{BDNF}$-infused mice; $\mathrm{SEM}=1.6$ and 0.4 respectively; $p=0.048$ by Student's $t$ test).

Intracerebroventricular BDNF administration has previously been shown to significantly increase the number of new cells added to the OB (Zigova et al., 1998; Benraiss et al., 2001). We therefore analyzed the OB of the mice we had infused with BDNF and vehicle for $14 \mathrm{~d}$. To label newly generated cells, mice were injected with BrdU every $4 \mathrm{~d}$, starting on the fourth day after pump implantation and ending $2 \mathrm{~d}$ before the mice were killed (Fig. 6A). Consistent with previous reports (Zigova et al., 1998; Benraiss et al., 2001), the vast majority of $\mathrm{BrdU}^{+}$cells in the $\mathrm{OB}$ were neuronal $(90.3 \%$ in vehicle-infused and $86.5 \%$ in BDNFinfused mice, as determined by $\mathrm{HuC/D}$ staining). Small numbers of $\mathrm{BrdU}^{+}$cells were identified as Olig $2^{+}$oligodendroglia $(4.3 \%$ in vehicle-infused and $4.2 \%$ in BDNF-infused mice) and Ibal ${ }^{+}$ microglia $(0.9 \%$ in vehicle-infused and $1.1 \%$ in BDNF-infused mice). Surprisingly, though, we did not detect any difference in the total number of $\mathrm{BrdU}^{+}$cells in the OB after $14 \mathrm{~d}$ of BDNF infusion (Fig. $6 \mathrm{D}, \mathrm{F} ; 352 \mathrm{vs} 348 \mathrm{BrdU}^{+}$cells/OB section in vehicle vs $B D N F-i n f u s e d$ mice; $S E M=26$ and 42 respectively; $p=0.93$ by Student's $t$ test). This result differs from previous findings, which reported 2 to threefold increases in $\mathrm{BrdU}^{+}$cells in the OB of BDNF-treated rats (Zigova et al., 1998; Benraiss et al., 2001). However, we did observe other known effects of BDNF: the weight of BDNF-infused mice dropped continuously, averaging $31.4 \%$ less than that of control mice by the 14 th day of treatment (Fig. 6B). Benraiss et al. (2001) reported a similar weight loss during their experiment. Because BDNF is a known appetite suppressant, (Pelleymounter et al., 1995; Kernie et al., 2000; Xu et al., 2003), this observation confirms that BDNF was being delivered and was biologically active throughout our experiment. As further corroboration of the quality of our BDNF solution, we observed that dorsal root ganglia (DRG) neurons responded to as little as $10 \mathrm{ng} / \mathrm{ml} \mathrm{BDNF}$ in vitro with extensive neurite outgrowth and an increased number of surviving neurons (supplemental Fig. 8, available at www.jneurosci.org as supplemental material) (Lindsay et al., 1985; Davies et al., 1986). At the end of the experiment, all pump reservoirs were nearly empty. Additionally, we visually confirmed on brain sections that the pump cannula penetrated into the lateral ventricle lumen in all mice analyzed (supplemental Fig. 9A, $B$, available at www.jneurosci.org as supplemental material) and we immunolabeled SVZ sections of pumpimplanted mice with a BDNF antibody to confirm the protein was being delivered (supplemental Fig. 10, available at www. jneurosci.org as supplemental material).

These findings are consistent with our in vitro observations. Adult SVZ astrocytes were cultured in subconfluent conditions with or without BDNF for $7 \mathrm{~d}$, then labeled for $1 \mathrm{~h}$ with BrdU (supplemental Fig. 11A,D, available at www.jneurosci.org as supplemental material). Alternatively, SVZ astrocytes from P3 pups were grown to confluence and then allowed to generate neuroblasts in the presence or absence of BDNF for $6 \mathrm{~d}$. We then added BrdU for $12 \mathrm{~h}$ before fixing the cultures (supplemental Fig. $11 B, E$, available at www.jneurosci.org as supplemental material). BDNF did not increase the number of labeled SVZ astrocytes or neuroblasts (supplemental Fig. 11G,H, available at www. jneurosci.org as supplemental material). We also cultured TrkB-KO and WT SVZ neuroblasts purified from GFP ${ }^{+} \mathrm{P} 3$ pups on a feeder layer of $\mathrm{GFP}^{-}$, non-neurogenic cortical astrocytes (supplemental Fig. 11C,F, available at www.jneurosci.org as supplemental material). Neither exposure to the BDNF ligand nor deletion of the TrkB receptor affected the total number of neuro- 
blasts after $5 \mathrm{~d}$ (supplemental Fig. $11 \mathrm{I}$, available at www.jneurosci.org as supplemental material) (see Materials and Methods for details).

Overall, our results suggest that BDNF delivered to the ventricle does not significantly enhance adult neurogenesis, contrary to what other laboratories have reported (Zigova et al., 1998; Benraiss et al., 2001), nor does it seem to affect proliferation or survival of SVZ astrocytes and neuroblasts in short-term cultures.

\section{BDNF inhibits rat neurogenesis}

One possible cause for the contradiction between the results reported above and those published by other groups is that we used mice as model organisms for our BDNF infusion experiments, whereas others used rats. Therefore, we tested whether mice and rats might differ in their ability to respond to BDNF, perhaps as a result of species-specific differences in expression of BDNF receptors. By in situ hybridization, we found considerable levels of TrkB mRNA in the adult rat SVZ, with the ependymal layer prominently labeled as well as patches of cells within the SVZ (Fig. $7 A$ ). However, as in mice, virtually no TrkB-FL was detected in the rat SVZ (Fig. 7D). This result shows that expression of TrkB isoforms is very similar in adult mice and rats.

We also characterized the SVZ expression of the low affinity neurotrophin receptor p75, to which BDNF also binds. Based on the staining pattern obtained with 2 different anti-p75 antibodies (detecting the receptor's intracellular or extracellular domains; see Materials and Methods), p75 is expressed by few cells in the adult mouse SVZ and RMS (Fig. 7C,F) (data not shown). This result is consistent with the low levels of p75 mRNA detected in the SVZ by RT-PCR (Fig. 1A). In adult rats, however, many more SVZ cells express p75 (Fig. $7 B, E$ ). We found large numbers of $\mathrm{p}^{+} 5^{+}$cells from the subcallosal area to the ventral tip of the lateral ventricle at all rostrocaudal levels of the rat SVZ, as well as on the medial wall of the lateral ventricle in more rostral sections. This expression pattern was confirmed using 5 different anti-p75 antibodies (detecting the receptor's intracellular or extracellular domains; see Materials and Methods). We also detected numerous $\mathrm{p} 5^{+}$cells in the adult rat RMS, although their numbers gradually decreased at increasingly rostral levels (data not shown). We detected many $\mathrm{p} 75^{+}$cells in the medial septum of both rats and mice (Fig. $7 B, C$ ), indicating that the antibodies used can function on tissue from both species. In both rats and mice, $\mathrm{p} 75^{+}$cells were often Mash1 ${ }^{+}$(Fig. $\left.7 E, F\right)$, a transcription factor strongly expressed by type C cells (Parras et al., 2004). This observation is consistent with previous findings suggesting that, in the SVZ, p75 $\mu \mathrm{m}(\boldsymbol{C}-\boldsymbol{F})$.
B
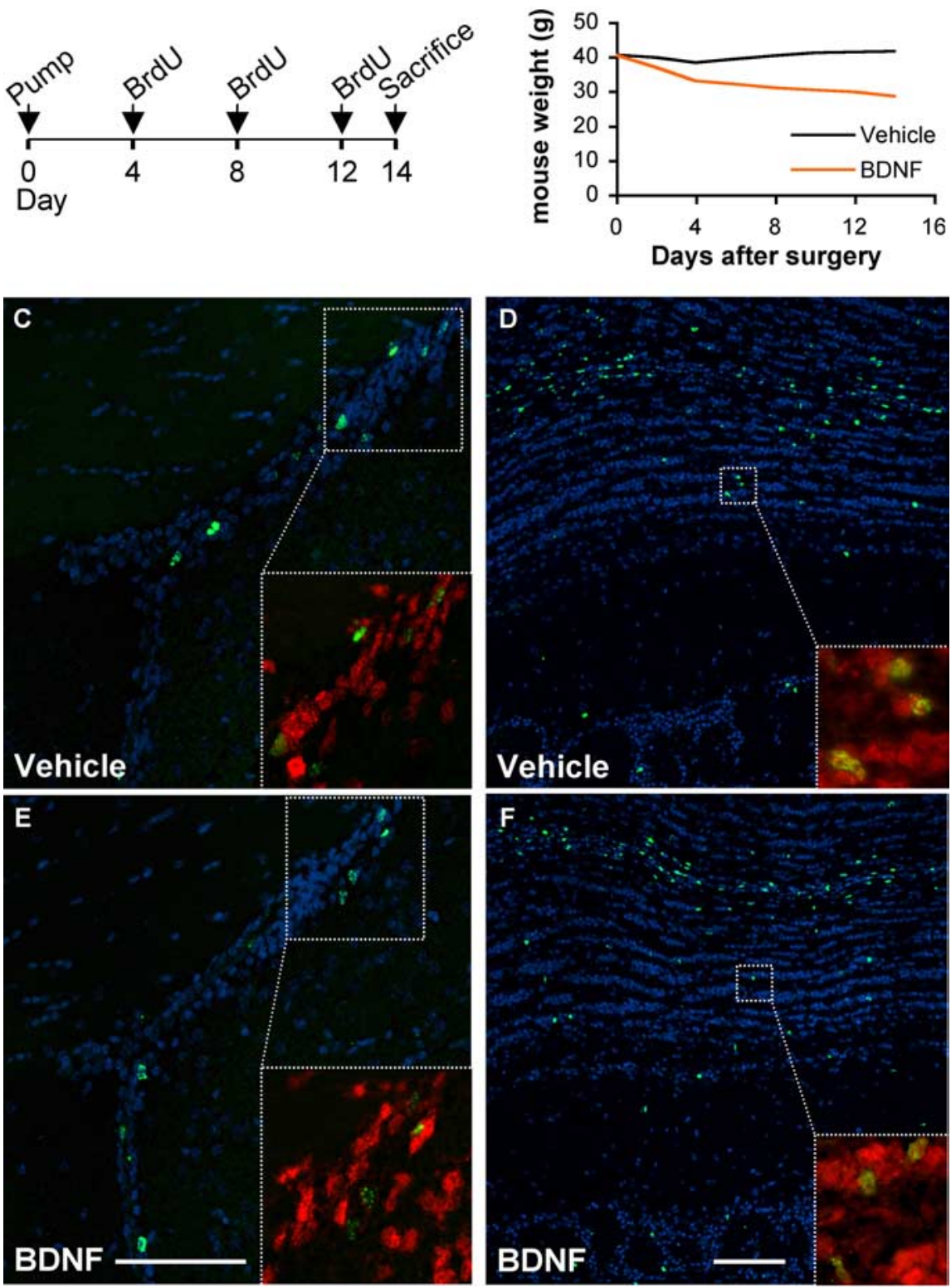

Figure 6. In vivo effect of $\mathrm{BDNF}$ infusion in adult mice. $A$, Experimental design: micro-osmotic pumps were implanted on $\mathrm{P} 90$ mice to infuse BDNF for $14 \mathrm{~d}$; BrdU was administered every $4 \mathrm{~d}$ by intraperitoneal injection; on day 14 , mice were killed for analysis. $\boldsymbol{B}$, Effect of BDNF infusion on mouse weight. $\boldsymbol{C}, \boldsymbol{E}$, Phosphorylated histone $\mathrm{H3}$ (pH3, green) staining ipsilateral to pump implant, in SVZ of vehicle $(\boldsymbol{C})$ and BDNF $(\boldsymbol{E})$ infused mice. $\boldsymbol{D}, \boldsymbol{F}$, BrdU (green) staining of 0 B ipsilateral to pump implant in vehicle $(\boldsymbol{D})$ and BDNF $(\boldsymbol{F})$ infused mice (see supplemental Fig. $12 A$, available at www.jneurosci.org as supplemental material, for BrdU quantification in all OB layers). SVZ inset $(\boldsymbol{C}, \boldsymbol{E}), \mathrm{pH} / \mathrm{Hu}$ (green/red); OB inset $(\boldsymbol{D}, \boldsymbol{F})$ : BrdU/Hu (green/red). Blue: DAPI (all panels). Scale bars: 100

is expressed mainly by type C cells (Giuliani et al., 2004; Young et al., 2007). We also detected p75 protein on a subpopulation of $\mathrm{PSA}_{\mathrm{NCAM}}{ }^{+}$cells in rat SVZ, indicating that some type A neuroblasts also express this receptor (Fig. $7 G$ ). p75 did not colocalize with GFAP (Fig. $7 H$ ).

In light of the striking difference in p75 expression in mouse and rat SVZ, we then tested whether rats would respond differently from mice to intraventricular BDNF infusions. We implanted microosmotic pumps in adult rats, delivering BDNF (1 $\mathrm{mg} / \mathrm{ml}$ ) or vehicle into the lateral ventricle for $14 \mathrm{~d}$. As with mice, rats were injected intraperitoneally (IP) with BrdU at day 4, 8 and 12 after pump implantation, then killed at day 14 (Fig. 8 A). Once again, the weight of BDNF-infused animals decreased, whereas 


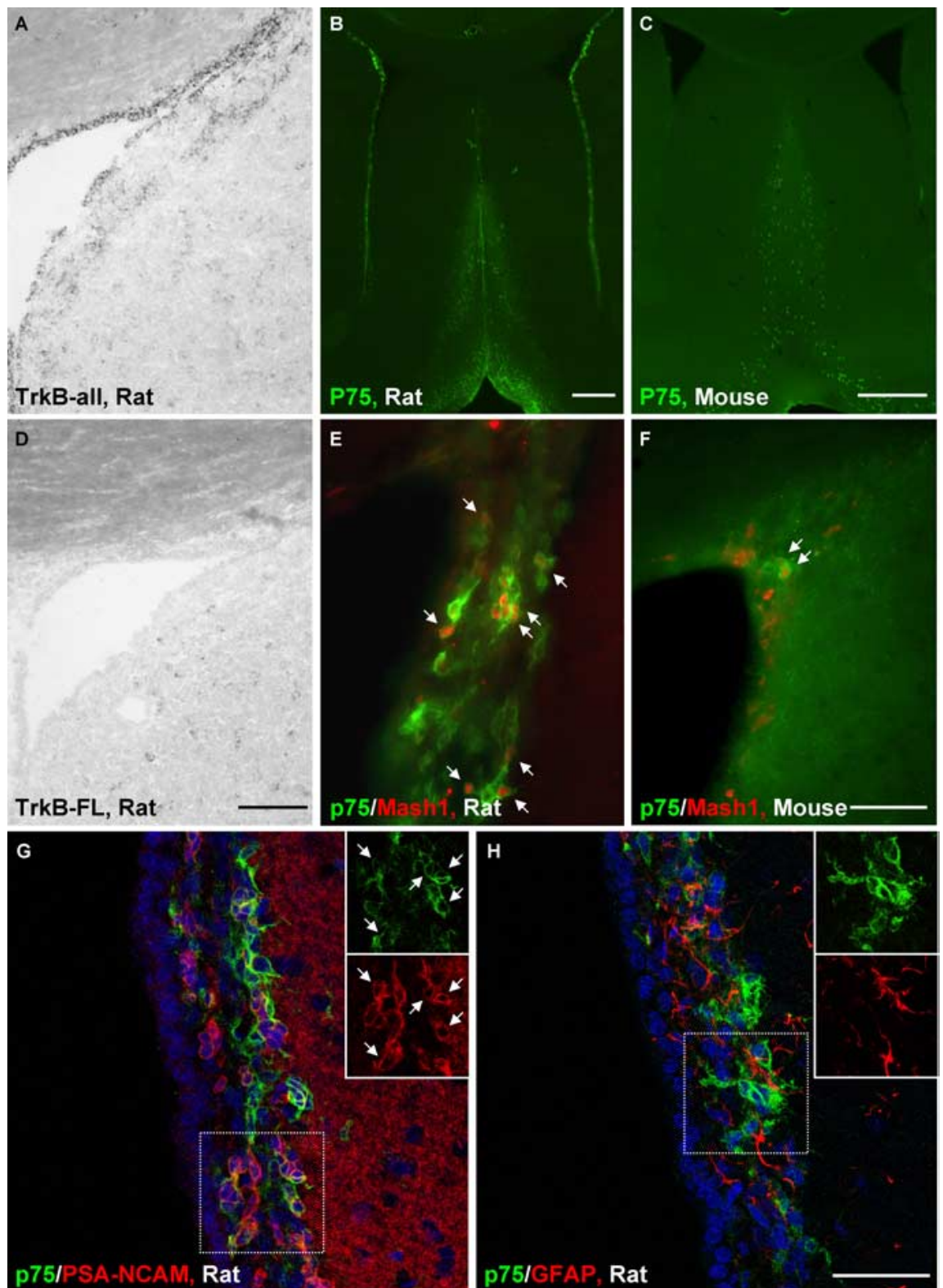

Figure 7. $\quad \mathrm{p} 75$ but not TrkB receptor expression is different in adult rat and mouse SVZ. $A, D$, In situ hybridization to detect all isoforms of TrkB (TrkB-all, $A$ ) shows strong staining in the ependymal layer and in some cells of the adult rat SVZ, whereas the full-length isoform of TrkB (TrkB-FL, D), although present in striatal cells, is undetectable in the rat SVZ. $\boldsymbol{B}, \mathrm{p} 75$ was detected by immunohistochemistry in many cells at all levels of the adult rat SVZ as well as in the medial septum. $C$, In contrast, very little p75 staining was detected in the adult mouse SVZ, although the medial septum contained again many p75 ${ }^{+}$cells. $\boldsymbol{E}, \boldsymbol{F}, \mathrm{p} 75^{+}$cells often coexpressed the transcription factor Mash1 (red) in both rat $(\boldsymbol{E})$ and mouse $(\boldsymbol{F})$ SVZ. G, $\boldsymbol{H}$, Confocal microscopy (single image) of adult rat SVZ reveals significant coexpression of p75 (green) with the neuroblast marker PSA-NCAM (G, red) but not with the astrocyte marker GFAP $(\boldsymbol{H}$, red). Insets show individual markers from boxed areas; arrows indicate several double-labeled cells (blue: DAPI). Scale bars: $(\boldsymbol{A}, \boldsymbol{D} ; \boldsymbol{E}, \boldsymbol{F}), 100 \mu \mathrm{m} ;(\boldsymbol{B}, \boldsymbol{C}), 500 \mu \mathrm{m} ;(\boldsymbol{G}, \boldsymbol{H}), 50 \mu \mathrm{m}$.

that of vehicle-infused animals increased (Fig. $8 \mathrm{~B}$ ). On the 14 th day of infusion, BDNF-treated rats weighed $44 \%$ less than control rats, having lost on average $13.7 \%$ of their original weight, indicating that BDNF was active and was delivered into the ventricle. As further confirmation, we visually checked on brain sections that the pump cannula penetrated into the lateral ventricle lumen in all rats used in this study (supplemental Fig. 9C,D, available at www.jneurosci.org as supplemental material). At the end of the infusion experiment, we collected the residual BDNF solution remaining in the pump of each rat separately and tested its activity using DRG cultures. DRG neurons responded strongly to BDNF in all cases (data not shown), as described above. Therefore, BDNF was delivered into the lateral ventricle and was biologically active throughout the experiment in every rat analyzed.

We stained $\mathrm{OB}$ sections of equivalent regions from 5 vehicle-treated and 6 BDNF-treated rats to count $\mathrm{BrdU}^{+}$cells. We found that BDNF-treated rats had fewer $\mathrm{BrdU}^{+}$cells in all layers of the $\mathrm{OB}$ (Fig. $8 C$; decrease values: $31.6 \%$ overall, $p=0.02 ; 37.3 \%$ in $\mathrm{OB}$ core, $p=0.02$; $23.5 \%$ in granular cell layer, $p=0.07$; $28.7 \%$ in external plexiform layer, $p=$ $0.03 ; 34.1 \%$ in glomerular layer, $p=$ 0.0004 ; p values determined by Student's $t$ test). As in mice, most $\mathrm{BrdU}^{+}$cells were neuronal $(83.4 \%$ and $77.7 \%$ in vehicle and BDNF-infused rats, respectively, based on $\mathrm{HuC/D}$ labeling), whereas some were labeled with the oligodendrocyte marker Olig2 (6.7\% and 8.4\% in vehicle and BDNFinfused rats, respectively) or with the microglial marker Ibal (1.9\% and $2.4 \%$ in vehicle and BDNF-infused rats, respectively).

We then analyzed the SVZ of the same rats to determine the cause of the apparent decrease in new neuron production among BDNF-treated animals. We found no effect of BDNF on apoptosis in the SVZ, as measured by TUNEL (374 vs 379 TUNEL $^{+}$cells/SVZ in vehicle vs BDNFinfused rats; $S E M=41$ and 45 respectively; $p=0.94$ by Student's $t$ test). Using the mitosis marker $\mathrm{pH} 3$, we detected a $20.1 \%$, statistically significant decrease in proliferation in the SVZ of rats infused with BDNF (23.8 vs $19.0 \mathrm{pH} 3^{+}$cells/section in vehicle vs BDNF-infused rats; $p=0.04$ by Student's $t$ test). Consistent with the decrease in proliferation, we found that the number of SVZ cells labeled by Mash1, a transcription factor expressed mainly by the highly proliferative type C cells (Parras et al., 2004), was also significantly reduced by $24.8 \%$ in BDNF-treated rats (99.9 vs 75.1 Mash1 $^{+}$ cells/imaged dorsal SVZ field in vehicle vs BDNF-infused rats; SEM $=7.6$ and 4.5 respectively; $p=0.02$ by Student's $t$ test).

Therefore, BDNF decreases the number of new $\mathrm{OB}$ neurons generated in adult rats. This effect may be caused by decreased proliferation among SVZ cells. This result is again in contrast with previous reports, which had stated that BDNF increases adult SVZ-derived neurogenesis in rats (Zigova et al., 1998; Benraiss et al., 2001). To more accurately compare our results to those of previous publications, we repeated the BDNF infusion experiment using a BrdU administration regimen identical to what was used by Zigova et al. (1998). We injected BDNF and vehicle-infused rats with $\operatorname{BrdU}(120 \mathrm{mg} / \mathrm{kg} \mathrm{IP})$ every $2 \mathrm{~h}$ over an $8 \mathrm{~h}$ period, totaling 5 injections, $4 \mathrm{~d}$ after the pump was implanted. Rats were infused for a total of $12 \mathrm{~d}$, during which time all BDNF-infused animals lost considerable weight (35.2\% less 
than control rats by the 12 th day of infusion, having lost on average $17.8 \%$ of their original weight), indicating that BDNF was active and was delivered into the ventricle. We then killed the rats, confirmed that pumps were emptied and that the cannula penetrated the ventricle, then counted the number of BrdU ${ }^{+}$cells in the $\mathrm{OB}$ ipsilateral to the pump. Once again, BDNF infusions did not increase the number of $\mathrm{BrdU}^{+}$cells in the $\mathrm{OB}$, causing instead a slight, statistically not significant decrease $(9.9 \%$ decrease, $p=0.4$ by Student's $t$ test) (supplemental Fig. 12C, available at www.jneurosci.org as supplemental material).

\section{Discussion}

We report that TrkB-TR, but not TrkB-FL, is strongly expressed in adult ependymal and SVZ type B cells and that TrkB-KO progenitors grafted into a WT brain continue to generate neurons in vivo for up to 6 months. Consistently, BDNF did not increase SVZ-to-OB neurogenesis in vivo and even decreased it in rats.

\section{TrkB is not expressed in}

\section{SVZ neuroblasts}

TrkB has been previously detected in the SVZ (Yan et al., 1994, 1997). Recent publications have reported TrkB expression in vivo on SVZ neuroblasts and not on astrocytes (Chiaramello et al., 2007; Bath et al., 2008). Our stainings with three different TrkB-specific antibodies as well as a TrkB: Tau-LacZ reporter mouse indicate that TrkB is expressed in ependyma and astrocytes but not in neuroblasts. This result was corroborated by depleting the SVZ of neuroblasts and type $\mathrm{C}$ cells with $\mathrm{AraC}$.

TrkB has been detected in cultured, SVZ-derived neurons (Kirschenbaum and Goldman, 1995; Gascon et al., 2005). However, TrkB levels in SVZ neuroblasts increase significantly in vitro (Gascon et al., 2005) and Kirschenbaum and Goldman (1995) stained for TrkB after $21 \mathrm{~d}$ in culture. Similarly, immature SVZ neuroblasts in vivo might not express TrkB until they begin maturing in the OB. In fact, we detected $\mathrm{TrkB}^{+}$cells in granular and glomerular OB layers by in situ hybridization (data not shown). This scenario would be consistent with both the expression data presented here and that of Kirschenbaum and Goldman (1995) and Gascon et al. (2005).

\section{p75 receptor expression in the $S V Z$}

Interestingly, mice and rats differ in their expression of p75. Previous work in the rat SVZ suggested that p75 is expressed mainly by proliferating, type C-like cells (Calzá et al., 1998; Giuliani et al., 2004; Young et al., 2007). Consistently, p75 ${ }^{+}$cells in the rat and mouse SVZ often colocalized with Mash1, a transcription factor expressed mainly by type C cells (Parras et al., 2004). Surprisingly, the mouse SVZ is almost entirely devoid of $\mathrm{p} 75^{+}$cells. Petratos et al. (2004) and Gascon et al. (2007) have reported similar findings. This difference might imply that mice and rats

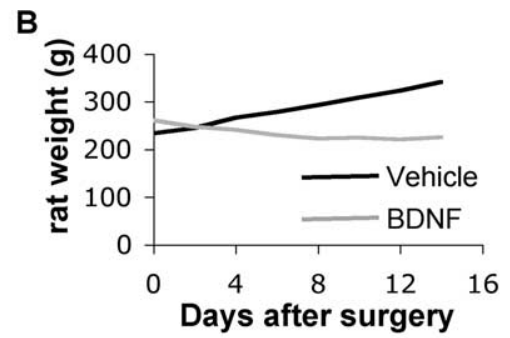

Vehicle

Olfactory Bulb

$\square \mathrm{BDNF}$

\begin{tabular}{|c|c|c|c|c|c|}
\hline \multicolumn{2}{|c|}{ D } & BrdU & TUNEL & $\mathrm{pH} 3$ & Mash1 \\
\hline n & SVZ & & & $\downarrow 22.5 \%(p=0.048)$ & \\
\hline$\Sigma$ & OB & $\leftrightarrow(p=0.93)$ & & & \\
\hline$\pi$ & SVZ & & $\leftrightarrow(p=0.94)$ & $\downarrow 20.1 \%(p=0.04)$ & $\downarrow 24.8 \%(p=0.02)$ \\
\hline$\ddot{\sim}$ & OB & $\downarrow 31.6 \%(p=0.02)$ & & & \\
\hline
\end{tabular}

Figure 8. In vivo effect of BDNF infusion in adult rats. $A$, Experimental design: micro-osmotic pumps were implanted on $\sim 250$ for analysis. $B$, Effect of BDNF infusion on rat weight. C, Quantification of BrdU staining in rat OB ipsilateral to pump; results are presented for all OB layers together (Total) as well as for each individual layer (Core; GCL, granular cell layer; EPL, externa

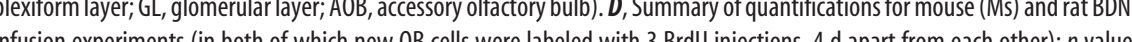
represent statistical significance by Student's t test; ${ }^{*} p<0.05,{ }^{* * *} p<0.001 . n=5$ animals/group for all mouse quantifications; $n=6$ animals/group for all rat quantifications, except BrdU ( $n=5$ Vehicle rats, 6 BDNF rats) and TUNEL ( $n=6$ Vehicle rats, 5 BDNF rats) quantifications. All values represent average \pm SEM.

use different signaling pathways to regulate $\mathrm{C}$ cell behavior. We also detected p75 in a significant subpopulation of PSA-NCAM ${ }^{+}$ cells in the rat SVZ, suggesting a greater role for p75 in SVZ neuroblasts than previously thought. p75 activation by BDNF can induce apoptosis, particularly if not coexpressed with Trk receptors (Casaccia-Bonnefil et al., 1999; Nykjaer et al., 2005). p75 activation can also induce cell cycle exit (Chittka and Chao, 1999; Salehi et al., 2000; Chittka et al., 2004; Wen et al., 2004; Vilar et al., 2006) and/or promote neuronal differentiation (Yamashita et al., 1999; Gascon et al., 2005). Hypothetically, TrkB-TR expressed in ependyma and SVZ astrocytes could control survival and/or differentiation of $\mathrm{p}^{+}{ }^{+}$type $\mathrm{C}$ cells and neuroblasts in a non-cell-autonomous manner, by limiting these cells' access to BDNF. Indeed, Biffo et al. (1995) have proposed that TrkB-TR ${ }^{+}$glia can form a barrier to BDNF diffusion in the brain, confining this neurotrophin's actions to specific regions.

\section{Does TrkB play a role in postnatal neurogenesis?}

Our grafting experiment shows that TrkB is not essential cellautonomously for SVZ neurogenesis. TrkB-KO mice exhibited fewer proliferating cells and more apoptotic cells in the SVZ and 
$\mathrm{OB}$ at birth, and 1 month-old TrkB heterozygotes had fewer new $\mathrm{OB}$ cells than controls. These effects are likely the result of the constitutive nature of these mutants: TrkB-KO mice also have increased apoptosis in the dentate gyrus, cortex, striatum, thalamus and cerebellum (Minichiello and Klein, 1996; Alcantara et al., 1997; Xu et al., 2000b).

Our data suggest that TrkB is not essential for survival of most new OB neurons. However, TrkB may have a selective role in regulating the maturation/survival of specific interneuron subtypes, rather than a generalized effect on SVZ neurogenesis. In fact, our results suggest that dopaminergic periglomerular interneurons are more affected by TrkB loss than other cell types analyzed. Because TH expression is activity-dependent (Baker et al., 1983), this effect could be the result of the known role of TrkB in the development of dendritic branches, synaptic formation and plasticity (McAllister et al., 1999; Cohen-Cory, 2002). TrkB may be important for other $\mathrm{OB}$ subpopulations not examined in this work. It was recently reported that loss of BDNF selectively decreases the number and dendritic complexity of Parvalbu$\min ^{+}$neurons in the OB external plexiform layer (Berghuis et al., 2006). Because few/no Parvalbumin ${ }^{+}$cells were made from our grafts after 6 months, we were unable to determine the effect of TrkB-KO on these neurons. For similar reasons, we also could not study the Calretinin ${ }^{+} \mathrm{OB}$ interneuron subpopulation.

\section{BDNF does not increase neuroblast production in vivo}

Our results suggest that exogenous BDNF delivered intraventricularly does not enhance SVZ neurogenesis and may even decrease it. These findings contrast with two previous studies in rats, in which BDNF delivered to the lateral ventricle induced a 2-3-fold increase in new OB cells (Zigova et al., 1998; Benraiss et al., 2001). Recently, other laboratories overexpressed BDNF in the rat and mouse SVZ and also could not detect an increase in new OB neurons (Henry et al., 2007; Reumers et al., 2008), although one group did observe more $\mathrm{BrdU}^{+}$cells in the RMS (Henry et al., 2007) and the other reported a small increase in new $\mathrm{OB}$ cells in the short term, followed by a significant decrease in the long term (Reumers et al., 2008). It is possible that BDNF effects on SVZ change over the period of infusion. If BDNF increases new neuron production by accelerating progenitor differentiation and/or favoring a neuronal rather than glial lineage (Ahmed et al., 1995; Cheng et al., 2003; Young et al., 2007), this increase could lead in the long run to a reduction in SVZ neuron production caused by a depletion of the progenitor pool. This interpretation could reconcile our findings with those of Young et al. (2007), who reported that BDNF increases neuronal production in neurosphere cultures. Alternatively, these might be in vitro effects that are not reproducible in vivo. Young et al. (2007) also report that BDNF acts on SVZ progenitors through $\mathrm{p75}$, which, as discussed above, can affect cell proliferation and differentiation. We detected a reduction in SVZ proliferation after $14 \mathrm{~d}$ of BDNF infusion in both mice and rats as well as fewer Mash1 ${ }^{+}$ cells in BDNF-infused rats. However, only in rats was this reduced proliferation accompanied by a decrease in OB neuronal recruitment. Rats may respond more quickly than mice to BDNF, perhaps because of their higher p75 levels, thus showing deficits in both SVZ and OB after $14 \mathrm{~d}$ of infusion. It is possible that similar reductions in new $\mathrm{OB}$ neurons may emerge in mice infused with BDNF for longer periods of time, as observed by Reumers et al. (2008).

A depletion of progenitor pools alone cannot explain the different results of previous studies versus ours, as all exposed the SVZ to BDNF for at least $12 \mathrm{~d}$. However, Zigova et al. (1998) and ourselves infused BDNF protein with microosmotic pumps, whereas Benraiss et al. (2001) induced BDNF overexpression using intraventricular adenoviral injections. Although the comparison is difficult, the viral method likely exposes SVZ cells to lower BDNF levels. Based on a rat CSF volume of $250 \mu \mathrm{l}$ and a turnover rate of $2 \mathrm{~h}$ (Bass and Lundborg, 1973), the CSF should contain $\sim 4$ $\mu \mathrm{g} / \mathrm{ml}$ exogenous BDNF in our pump experiments, whereas Benraiss et al. (2001) report $2 \mathrm{ng} / \mathrm{ml}$ BDNF in the CSF. However, we used the same BDNF doses as Zigova et al. (1998) and several other laboratories have reported biological effects when infusing BDNF at similar doses (Siuciak et al., 1996; Scharfman et al., 2005; Givalois et al., 2006). The weight reduction observed in BDNF-infused animals indicates that this neurotrophin elicited biological effects in our experiments as well.

Another difference between previous publications and ours is the BrdU administration regimen. To directly determine whether that could modify the outcome of BDNF infusions, we repeated this experiment following the same BrdU administration protocol used in Zigova et al. (1998). We detected fewer BrdU ${ }^{+}$cells in the $\mathrm{OB}$ of BDNF-infused rats, indicating that the dose or timing of BrdU delivery is not the cause of the discrepancy between our results and those of Zigova et al. (1998). We detected a greater decrease in $\mathrm{OB}$ labeling in rats injected with BrdU on days 4,8 and 12 of BDNF infusion. This protocol is likely more sensitive at detecting the effects of BDNF on the SVZ because it labels cells generated throughout the infusion period rather than at a single, earlier time point (supplemental Fig. 12, available at www. jneurosci.org as supplemental material).

We did not analyze the effect of our infusions on brain regions other than the SVZ/OB, so it is possible that BDNF enhances neurogenesis elsewhere in the brain (Benraiss et al., 2001; Pencea et al., 2001; Chmielnicki et al., 2004; Scharfman et al., 2005). Nonetheless, more research is clearly needed to understand the role of this neurotrophin in endogenous neurogenesis before it can be considered promising for therapeutic purposes.

\section{References}

Ahmed S, Reynolds BA, Weiss S (1995) BDNF enhances the differentiation but not the survival of CNS stem cell-derived neuronal precursors. J Neurosci 15:5765-5778.

Alcantara S, Frisen J, del Rio JA, Soriano E, Barbacid M, Silos-Santiago I (1997) TrkB signaling is required for postnatal survival of CNS neurons and protects hippocampal and motor neurons from axotomy-induced cell death. J Neurosci 17:3623-3633.

Alvarez-Buylla A, Garcia-Verdugo JM (2002) Neurogenesis in adult subventricular zone. J Neurosci 22:629-634.

Anderson KD, Alderson RF, Altar CA, DiStefano PS, Corcoran TL, Lindsay RM, Wiegand SJ (1995) Differential distribution of exogenous BDNF, NGF, and NT-3 in the brain corresponds to the relative abundance and distribution of high-affinity and low-affinity neurotrophin receptors. J Comp Neurol 357:296-317.

Baker H, Kawano T, Margolis FL, Joh TH (1983) Transneuronal regulation of tyrosine hydroxylase expression in olfactory bulb of mouse and rat. J Neurosci 3:69-78.

Barker PA (2004) p75NTR is positively promiscuous: novel partners and new insights. Neuron 42:529-533.

Bass NH, Lundborg P (1973) Postnatal development of bulk flow in the cerebrospinal fluid system of the albino rat: clearance of carboxyl-(14 C)inulin after intrathecal infusion. Brain Res 52:323-332.

Bath KG, Mandairon N, Jing D, Rajagopal R, Kapoor R, Chen ZY, Khan T, Proenca CC, Kraemer R, Cleland TA, Hempstead BL, Chao MV, Lee FS (2008) Variant brain-derived neurotrophic factor (Val66Met) alters adult olfactory bulb neurogenesis and spontaneous olfactory discrimination. J Neurosci 28:2383-2393.

Benraiss A, Chmielnicki E, Lerner K, Roh D, Goldman SA (2001) Adenoviral brain-derived neurotrophic factor induces both neostriatal and olfac- 
tory neuronal recruitment from endogenous progenitor cells in the adult forebrain. J Neurosci 21:6718-6731.

Berghuis P, Agerman K, Dobszay MB, Minichiello L, Harkany T, Ernfors P (2006) Brain-derived neurotrophic factor selectively regulates dendritogenesis of parvalbumin-containing interneurons in the main olfactory bulb through the PLCgamma pathway. J Neurobiol 66:1437-1451.

Biffo S, Offenhauser N, Carter BD, Barde YA (1995) Selective binding and internalisation by truncated receptors restrict the availability of BDNF during development. Development 121:2461-2470.

Calzá L, Giardino L, Pozza M, Bettelli C, Micera A, Aloe L (1998) Proliferation and phenotype regulation in the subventricular zone during experimental allergic encephalomyelitis: In vivo evidence of a role for nerve growth factor. Proc Natl Acad Sci U S A 95:3209-3214.

Carleton A, Petreanu LT, Lansford R, Alvarez-Buylla A, Lledo PM (2003) Becoming a new neuron in the adult olfactory bulb. Nat Neurosci 6:507-518.

Casaccia-Bonnefil P, Gu C, Khursigara G, Chao MV (1999) p75 neurotrophin receptor as a modulator of survival and death decisions. Microsc Res Tech 45:217-224.

Chao MV (2003) Neurotrophins and their receptors: a convergence point for many signalling pathways. Nat Rev Neurosci 4:299-309.

Cheng A, Wang S, Cai J, Rao MS, Mattson MP (2003) Nitric oxide acts in a positive feedback loop with BDNF to regulate neural progenitor cell proliferation and differentiation in the mammalian brain. Dev Biol 258:319-333.

Chiaramello S, Dalmasso G, Bezin L, Marcel D, Jourdan F, Peretto P, Fasolo A, De Marchis S (2007) BDNF/ TrkB interaction regulates migration of SVZ precursor cells via PI3-K and MAP-K signalling pathways. Eur J Neurosci 26:1780-1790.

Chiasson BJ, Tropepe V, Morshead CM, Van der Kooy D (1999) Adult mammalian forebrain ependymal and subependymal cells demonstrate proliferative potential, but only subependymal cells have neural stem cell characteristics. J Neurosci 19:4462-4471.

Chittka A, Chao MV (1999) Identification of a zinc finger protein whose subcellular distribution is regulated by serum and nerve growth factor. Proc Natl Acad Sci U S A 96:10705-10710.

Chittka A, Arevalo JC, Rodriguez-Guzman M, Perez P, Chao MV, Sendtner M (2004) The p75NTR-interacting protein SC1 inhibits cell cycle progression by transcriptional repression of cyclin E. J Cell Biol 164:985-996.

Chmielnicki E, Benraiss A, Economides AN, Goldman SA (2004) Adenovirally expressed noggin and brain-derived neurotrophic factor cooperate to induce new medium spiny neurons from resident progenitor cells in the adult striatal ventricular zone. J Neurosci 24:2133-2142.

Cohen-Cory S (2002) The developing synapse: construction and modulation of synaptic structures and circuits. Science 298:770-776.

Craig CG, Tropepe V, Morshead CM, Reynolds BA, Weiss S, Van der Kooy D (1996) In vivo growth factor expansion of endogenous subependymal neural precursor cell populations in the adult mouse brain. J Neurosci 16:2649-2658.

Davies AM, Thoenen H, Barde YA (1986) The response of chick sensory neurons to brain-derived neurotrophic factor. J Neurosci 6:1897-1904.

Dechant G, Barde YA (2002) The neurotrophin receptor p75(NTR): novel functions and implications for diseases of the nervous system. Nat Neurosci 5:1131-1136.

Doetsch F, Alvarez-Buylla A (1996) Network of tangential pathways for neuronal migration in adult mammalian brain. Proc Natl Acad Sci U S A 93:14895-14900.

Doetsch F, Garcia-Verdugo JM, Alvarez-Buylla A (1997) Cellular composition and three-dimensional organization of the subventricular germinal zone in the adult mammalian brain. J Neurosci 17:5046-5061.

Doetsch F, Garcia-Verdugo JM, Alvarez-Buylla A (1999a) Regeneration of a germinal layer in the adult mammalian brain. Proc Natl Acad Sci U S A 96:11619-11624.

Doetsch F, Caille I, Lim DA, Garcia-Verdugo JM, Alvarez-Buylla A (1999b) Subventricular zone astrocytes are neural stem cells in the adult mammalian brain. Cell 97:703-716.

Fior R, Henrique D (2005) A novel hes5/hes6 circuitry of negative regulation controls Notch activity during neurogenesis. Dev Biol 281:318-333.

Gascon E, Vutskits L, Jenny B, Durbec P, Kiss JZ (2007) PSA-NCAM in postnatally generated immature neurons of the olfactory bulb: a crucial role in regulating p75 expression and cell survival. Development 134:1181-1190.

Gascon E, Vutskits L, Zhang H, Barral-Moran MJ, Kiss PJ, Mas C, Kiss JZ (2005) Sequential activation of p75 and TrkB is involved in dendritic development of subventricular zone-derived neuronal progenitors in vitro. Eur J Neurosci 21:69-80.

Giuliani A, D’Intino G, Paradisi M, Giardino L, Calza L (2004) p75(NTR)immunoreactivity in the subventricular zone of adult male rats: expression by cycling cells. J Mol Histol 35:749-758.

Givalois L, Naert G, Tapia-Arancibia L, Arancibia S (2006) Involvement of brain-derived neurotrophic factor in the regulation of hypothalamic somatostatin in vivo. J Endocrinol 188:425-433.

Hadjantonakis AK, Gertsenstein M, Ikawa M, Okabe M, Nagy A (1998) Generating green fluorescent mice by germline transmission of green fluorescent ES cells. Mech Dev 76:79-90.

Henry RA, Hughes SM, Connor B (2007) AAV-mediated delivery of BDNF augments neurogenesis in the normal and quinolinic acid-lesioned adult rat brain. Eur J Neurosci 25:3513-3525.

Horner PJ, Palmer TD (2003) New roles for astrocytes: the nightlife of an 'astrocyte'. La vida loca! Trends Neurosci 26:597-603.

Huang EJ, Reichardt LF (2001) Neurotrophins: roles in neuronal development and function. Annu Rev Neurosci 24:677-736.

Huber LJ, Chao MV (1995) Mesenchymal and neuronal cell expression of the p75 neurotrophin receptor gene occur by different mechanisms. Dev Biol 167:227-238.

Jackson EL, Garcia-Verdugo JM, Gil-Perotin S, Roy M, Quinones-Hinojosa A, Vandenberg S, Alvarez-Buylla A (2006) PDGFRalpha-positive B cells are neural stem cells in the adult SVZ that form glioma-like growths in response to increased PDGF signaling. Neuron 51:187-199.

Jankovski A, Sotelo C (1996) Subventricular zone-olfactory bulb migratory pathway in the adult mouse: cellular composition and specificity as determined by heterochronic and heterotopic transplantation. J Comp Neurol 371:376-396.

Kernie SG, Liebl DJ, Parada LF (2000) BDNF regulates eating behavior and locomotor activity in mice. EMBO J 19:1290-1300.

Kirschenbaum B, Goldman SA (1995) Brain-derived neurotrophic factor promotes the survival of neurons arising from the adult rat forebrain subependymal zone. Proc Natl Acad Sci U S A 92:210-214.

Klein R, Parada LF, Coulier F, Barbacid M (1989) trkB, a novel tyrosine protein kinase receptor expressed during mouse neural development. EMBO J 8:3701-3709.

Klein R, Conway D, Parada LF, Barbacid M (1990) The trkB tyrosine protein kinase gene codes for a second neurogenic receptor that lacks the catalytic kinase domain. Cell 61:647-656.

Kohwi M, Osumi N, Rubenstein JL, Alvarez-Buylla A (2005) Pax6 is required for making specific subpopulations of granule and periglomerular neurons in the olfactory bulb. J Neurosci 25:6997-7003.

Kohwi M, Petryniak MA, Long JE, Ekker M, Obata K, Yanagawa Y, Rubenstein JL, Alvarez-Buylla A (2007) A subpopulation of olfactory bulb GABAergic interneurons is derived from Emx1- and Dlx5/6-expressing progenitors. J Neurosci 27:6878-6891.

Kokoeva MV, Yin H, Flier JS (2005) Neurogenesis in the hypothalamus of adult mice: potential role in energy balance. Science 310:679-683.

Kosaka K, Aika Y, Toida K, Heizmann CW, Hunziker W, Jacobowitz DM, Nagatsu I, Streit P, Visser TJ, Kosaka T (1995) Chemically defined neuron groups and their subpopulations in the glomerular layer of the rat main olfactory bulb. Neurosci Res 23:73-88.

Kuhn HG, Winkler J, Kempermann G, Thal LJ, Gage FH (1997) Epidermal growth factor and fibroblast growth factor-2 have different effects on neural progenitors in the adult rat brain. J Neurosci 17:5820-5829.

Lewandoski M, Meyers EN, Martin GR (1997) Analysis of Fgf8 gene function in vertebrate development. Cold Spring Harb Symp Quant Biol 62:159-168.

Lie DC, Song H, Colamarino SA, Ming GL, Gage FH (2004) Neurogenesis in the adult brain: new strategies for central nervous system diseases. Annu Rev Pharmacol Toxicol 44:399-421.

Lim DA, Alvarez-Buylla A (1999) Interaction between astrocytes and adult subventricular zone precursors stimulates neurogenesis. Proc Natl Acad Sci U S A 96 96:7526-7531.

Lim DA, D. TA, Trevejo JM, Herrera DG, García-Verdugo JM, Alvarez-Buylla A (2000) Noggin antagonizes BMP signaling to create a niche for adult neurogenesis. Neuron 28:713-726.

Lindsay RM, Thoenen H, Barde YA (1985) Placode and neural crest-derived sensory neurons are responsive at early developmental stages to brainderived neurotrophic factor. Dev Biol 112:319-328. 
Lois C, Alvarez-Buylla A (1994) Long-distance neuronal migration in the adult mammalian brain. Science 264:1145-1148.

Lois C, Garcia-Verdugo JM, Alvarez-Buylla A (1996) Chain migration of neuronal precursors. Science 271:978-981.

Luskin MB (1993) Restricted proliferation and migration of postnatally generated neurons derived from the forebrain subventricular zone. Neuron 11:173-189.

McAllister AK, Katz LC, Lo DC (1999) Neurotrophins and synaptic plasticity. Annu Rev Neurosci 22:295-318.

Middlemas DS, Lindberg RA, Hunter T (1991) trkB, a neural receptor protein-tyrosine kinase: evidence for a full-length and two truncated receptors. Mol Cell Biol 11:143-153.

Minichiello L, Klein R (1996) TrkB and TrkC neurotrophin receptors cooperate in promoting survival of hippocampal and cerebellar granule neurons. Genes Dev 10:2849-2858.

Morshead CM, Reynolds BA, Craig CG, McBurney MW, Staines WA, Morassutti D, Weiss S, van der Kooy D (1994) Neural stem cells in the adult mammalian forebrain: a relatively quiescent subpopulation of subependymal cells. Neuron 13:1071-1082.

Neet KE, Campenot RB (2001) Receptor binding, internalization, and retrograde transport of neurotrophic factors. Cell Mol Life Sci 58:1021-1035.

Nykjaer A, Willnow TE, Petersen CM (2005) p75NTR-live or let die. Curr Opin Neurobiol 15:49-57.

Parras CM, Galli R, Britz O, Soares S, Galichet C, Battiste J, Johnson JE, Nakafuku M, Vescovi A, Guillemot F (2004) Mash1 specifies neurons and oligodendrocytes in the postnatal brain. EMBO J 23:4495-4505.

Pelleymounter MA, Cullen MJ, Wellman CL (1995) Characteristics of BDNF-induced weight loss. Exp Neurol 131:229-238.

Pencea V, Bingaman KD, Wiegand SJ, Luskin MB (2001) Infusion of brainderived neurotrophic factor into the lateral ventricle of the adult rat leads to new neurons in the parenchyma of the striatum, septum, thalamus, and hypothalamus. J Neurosci 21:6706-6717.

Peretto P, Merighi A, Fasolo A, Bonfanti L (1997) Glial tubes in the rostral migratory stream of the adult rat. Brain Res Bull 42:9-21.

Petratos S, Gonzales MF, Azari MF, Marriott M, Minichiello RA, Shipham KA, Profyris C, Nicolaou A, Boyle K, Cheema SS, Kilpatrick TJ (2004) Expression of the low-affinity neurotrophin receptor, p75(NTR), is upregulated by oligodendroglial progenitors adjacent to the subventricular zone in response to demyelination. Glia 48:64-75.

Petreanu L, Alvarez-Buylla A (2002) Maturation and death of adult-born olfactory bulb granule neurons: role of olfaction. J Neurosci

Philpot BD, Lim JH, Brunjes PC (1997) Activity-dependent regulation of calcium-binding proteins in the developing rat olfactory bulb. J Comp Neurol 387:12-26.

Reumers V, Deroose CM, Krylyshkina O, Nuyts J, Geraerts M, Mortelmans L, Gijsbers R, Van Den Haute C, Debyser Z, Baekelandt V (2008) Noninvasive and quantitative monitoring of adult neuronal stem cell migration in mouse brain using bioluminescence imaging. Stem Cells 26:2382-2390.

Rogers JH (1992) Immunohistochemical markers in rat brain: colocalization of calretinin and calbindin-D28k with tyrosine hydroxylase. Brain Res 587:203-210.

Salehi AH, Roux PP, Kubu CJ, Zeindler C, Bhakar A, Tannis LL, Verdi JM, Barker PA (2000) NRAGE, a novel MAGE protein, interacts with the p75 neurotrophin receptor and facilitates nerve growth factor-dependent apoptosis. Neuron 27:279-288.

Scharfman H, Goodman J, Macleod A, Phani S, Antonelli C, Croll S (2005)
Increased neurogenesis and the ectopic granule cells after intrahippocampal BDNF infusion in adult rats. Exp Neurol 192:348-356.

Schinder AF, Poo M (2000) The neurotrophin hypothesis for synaptic plasticity. Trends Neurosci 23:639-645.

Shingo T, Sorokan ST, Shimazaki T, Weiss S (2001) Erythropoietin regulates the in vitro and in vivo production of neuronal progenitors by mammalian forebrain neural stem cells. J Neurosci 21:9733-9743.

Shingo T, Gregg C, Enwere E, Fujikawa H, Hassam R, Geary C, Cross JC, Weiss S (2003) Pregnancy-stimulated neurogenesis in the adult female forebrain mediated by prolactin. Science 299:117-120.

Siuciak JA, Boylan C, Fritsche M, Altar CA, Lindsay RM (1996) BDNF increases monoaminergic activity in rat brain following intracerebroventricular or intraparenchymal administration. Brain Res 710:11-20.

Vilar M, Murillo-Carretero M, Mira H, Magnusson K, Besset V, Ibanez CF (2006) Bex1, a novel interactor of the p75 neurotrophin receptor, links neurotrophin signaling to the cell cycle. EMBO J 25:1219-1230.

Wen CJ, Xue B, Qin WX, Yu M, Zhang MY, Zhao DH, Gao X, Gu JR, Li CJ (2004) hNRAGE, a human neurotrophin receptor interacting MAGE homologue, regulates $\mathrm{p} 53$ transcriptional activity and inhibits cell proliferation. FEBS Lett 564:171-176.

Weskamp G, Reichardt LF (1991) Evidence that biological activity of NGF is mediated through a novel subclass of high affinity receptors. Neuron 6:649-663.

Xu B, Gottschalk W, Chow A, Wilson RI, Schnell E, Zang K, Wang D, Nicoll RA, Lu B, Reichardt LF (2000a) The role of brain-derived neurotrophic factor receptors in the mature hippocampus: modulation of long-term potentiation through a presynaptic mechanism involving TrkB. J Neurosci 20:6888-6897.

Xu B, Zang K, Ruff NL, Zhang YA, McConnell SK, Stryker MP, Reichardt LF (2000b) Cortical degeneration in the absence of neurotrophin signaling: dendritic retraction and neuronal loss after removal of the receptor TrkB. Neuron 26:233-245.

Xu B, Goulding EH, Zang K, Cepoi D, Cone RD, Jones KR, Tecott LH, Reichardt LF (2003) Brain-derived neurotrophic factor regulates energy balance downstream of melanocortin-4 receptor. Nat Neurosci 6:736-742.

Yamashita T, Tucker KL, Barde YA (1999) Neurotrophin binding to the p75 receptor modulates Rho activity and axonal outgrowth. Neuron 24:585-593.

Yan Q, Matheson C, Sun J, Radeke MJ, Feinstein SC, Miller JA (1994) Distribution of intracerebral ventricularly administered neurotrophins in rat brain and its correlation with trk receptor expression. Exp Neurol 127:23-36.

Yan Q, Radeke MJ, Matheson CR, Talvenheimo J, Welcher AA, Feinstein SC (1997) Immunocytochemical localization of TrkB in the central nervous system of the adult rat. J Comp Neurol 378:135-157.

Young KM, Merson TD, Sotthibundhu A, Coulson EJ, Bartlett PF (2007) p75 neurotrophin receptor expression defines a population of BDNFresponsive neurogenic precursor cells. J Neurosci 27:5146-5155.

Zheng W, Nowakowski RS, Vaccarino FM (2004) Fibroblast growth factor 2 is required for maintaining the neural stem cell pool in the mouse brain subventricular zone. Dev Neurosci 26:181-196.

Zhou X-F, Zettler C, Rush RA (1994) An improved procedure for the immunohistochemical localization of nerve growth factor-like immunoreactivity. J Neurosci Methods 54:95-102.

Zigova T, Pencea V, Wiegand SJ, Luskin MB (1998) Intraventricular administration of BDNF increases the number of newly generated neurons in the adult olfactory bulb. Mol Cell Neurosci 11:234-245. 